\title{
Cytotype diversity and genome size variation in Knautia (Caprifoliaceae, Dipsacoideae)
}

\author{
Božo Frajman ${ }^{1 \dagger}$, Ivana Rešetnik ${ }^{2 \dagger}$, Hanna Weiss-Schneeweiss ${ }^{3 *}$, Friedrich Ehrendorfer ${ }^{3}$ and Peter Schönswetter ${ }^{1}$
}

\begin{abstract}
Background: Polyploidisation is one of the most important mechanisms in the evolution of angiosperms. As in many other genera, formation of polyploids has significantly contributed to diversification and radiation of Knautia (Caprifoliaceae, Dipsacoideae). Comprehensive studies of fine- and broad-scale patterns of ploidy and genome size (GS) variation are, however, still limited to relatively few genera and little is known about the geographic distribution of ploidy levels within these genera. Here, we explore ploidy and GS variation in Knautia based on a near-complete taxonomic and comprehensive geographic sampling.

Results: Genome size is a reliable indicator of ploidy level in Knautia, even if monoploid genome downsizing is observed in the polyploid cytotypes. Twenty-four species studied are diploid, 16 tetraploid and two hexaploid, whereas ten species possess two, and two species possess three ploidy levels. Di- and tetraploids are distributed across most of the distribution area of Knautia, while hexaploids were sampled in the Balkan and Iberian Peninsulas and the Alps.

Conclusions: We show that the frequency of polyploidisation is unevenly distributed in Knautia both in a geographic and phylogenetic context. Monoploid GS varies considerably among three evolutionary lineages (sections) of Knautia, but also within sections Trichera and Tricheroides, as well as within some of the species. Although the exact causes of this variation remain elusive, we demonstrate that monoploid GS increases significantly towards the limits of the genus' distribution.
\end{abstract}

Keywords: Chromosome numbers, Cytotype diversity, Genome downsizing, Genome size, Knautia, Polyploidy

\section{Background}

The evolution of almost all angiosperm lineages is characterised by numerous polyploidisation events [1] that significantly contributed to their diversification and radiation [2-4]. Polyploidisation can directly influence gene flow within and among taxa [5] and often confers instantaneous speciation [6]. On long-terms it may govern habitat preferences [7] and consequently bear on the distribution of taxa [6]. The effects of polyploidisation are, however, far from uniform and may have an impact on species morphology, physiology and interactions with the environment [8]. Therefore, knowledge of the ploidy level variation within and among taxa is of principal importance for understanding the

\footnotetext{
*Correspondence: hanna.schneeweiss@univie.ac.at

${ }^{\dagger}$ Equal contributors

${ }^{3}$ Department of Botany and Biodiversity Research, University of Vienna, Rennweg 14, A-1030 Vienna, Austria

Full list of author information is available at the end of the article
}

evolutionary pathways in any plant group and facilitates the interpretation of phylogenetic relationships.

The nuclear DNA content may vary considerably among closely related species but is remarkably constant within most species [9-11], thus serving as an important taxonomic character [8]. For some species, however, significant variation among populations of the same ploidy level has been demonstrated, which is often geographically structured [12-14]. In addition, it has been shown that several ploidy level cytotypes (for simplicity, in the following we restrict the term "cytotype" to ploidy levels) exist within some species [12-16], and such intraspecific polyploids often have multiple origins [17]. The genome size (GS) of polyploids is expected to increase in direct proportion with ploidy level in recently formed polyploid series, whereas in older polyploids a significant decrease of monoploid GS, termed genome downsizing [18], may take place [14, 19-21]. Increase of monoploid GS in polyploids in comparison to diploid 
progenitors is less well documented and probably less common (e.g., Hordeum, [22]; Nicotiana, [23]; Melampodium, [24]).

Flow cytometry (FCM; see [8] and references therein), a high-throughput technique for the estimation of DNA content, has become an essential tool in evolutionary and systematic research in vascular plants. In recent years its large-scale application has been pivotal for elucidating polyploid speciation events, infraspecific ploidy variation and ecological differentiation of cytotypes; furthermore, flow cytometric data have supplemented phylogenetic evidence [12, 14, 25-27]. Nevertheless, the understanding of fine and broad scale patterns of ploidy variation is limited to relatively few species, and studies exploring variation in ploidy level and/or GS within taxa from different geographic areas are much needed [28], as are studies covering entire species-rich genera. Detailed cytogeographical studies at the genus level are rare (but see, [29-31]), whereas numerous studies have focussed on particular polyploid species complexes [7, 12-14, 32].

The genus Knautia L. (Caprifoliaceae, Dipsacoideae) comprises 50-55 species distributed in western Eurasia and northwestern Africa. The highest species diversity is in southern and southeastern Europe, especially the Alps and the Balkan Peninsula. Knautia species inhabit dry grasslands, wet meadows, alpine grasslands, forests, and ruderal communities [33, 34]. The traditional division of Knautia into the mostly perennial sect. Trichera encompassing the majority of taxa as well as the annual, species-poor sections sect. Tricheroides (K. byzantina, K. integrifolia) and sect. Knautia (K. orientalis; [35]) has recently been confirmed phylogenetically, but the position of $K$. degenii was ambiguous, either in sect. Knautia or sect. Tricheroides [34]. The three sections are characterised by karyotypes $\mathrm{A}, \mathrm{B}$ and $\mathrm{C}$, respectively, which differ in basic chromosome number and/or karyotype structure [35-37]. The perennial sect. Trichera is characterized by $x=10$ and karyotype A, with ploidy levels ranging from diploids via tetraploids to hexaploids $[35,36]$. In contrast, the species in the annual sections are exclusively diploid with $x=10$ (sect. Tricheroides, karyotype B) and $x=8$ (sect. Knautia, karyotype C). They are restricted to the eastern Balkan Peninsula and northwestern Anatolia; an exception is K. integrifolia, which extends its range to the Iberian Peninsula [36].

Sect. Trichera is characterized by the lack of clear and reliable morphological differential characters and a high incidence of hybridisation [34, 36]; it qualifies as a textbook example for a taxonomically difficult group. In the most comprehensive treatment of sect. Trichera based on morphology, distribution patterns and ploidy level, Ehrendorfer [35] has placed all taxa into eleven informal groups, most of which were recently shown to be non-monophyletic ([34], Frajman et al., unpubl. res.). Ehrendorfer [35] demonstrated that several species contain multiple ploidy levels (e.g., di- and tetraploid $K$. arvensis and $K$. drymeia, or tetra- and hexaploid $K$. dipsacifolia), but none of the species includes all three ploidy levels. This was also confirmed by subsequent karyological studies [38-43]. Recently, Kolár et al. [44] used flow cytometry to investigate patterns of ploidy variation in $K$. arvensis in Central Europe, and Temsch and Greilhuber [45] as well as Siljak-Yakovlev et al. [46] provided GS values for eight taxa and one taxon, respectively.

The aim of the present study is to explore GS variation and the incidence of polyploidy within the genus Knautia based on a comprehensive taxonomic and geographic sampling of 381 populations of 54 Knautia species, mostly from sect. Trichera. Our specific aims were (1) to screen ploidy levels and to estimate GS in order to determine geographical patterns of cytotype distributions as well as to identify populations and species with multiple ploidy levels; (2) to test previously published karyological records and to determine chromosome numbers for taxa with uncertain ploidy level; (3) to prove that GS allows reliable inference of ploidy levels in Knautia by using a combination of flow cytometry and chromosome number estimation in several taxa, (4) to test if genome downsizing is associated with polyploid genome evolution in Knautia, and (5) to explore how GS evolved in different phylogenetic lineages of diploid Knautia.

\section{Results}

\section{Chromosome numbers}

Chromosome numbers were established for 15 individuals from 14 Knautia species (Table 1, Fig. 1). Three ploidy levels were recorded, diploids $(2 n=2 x=20)$, tetraploids $(2 n=4 x=40)$ and hexaploids $(2 n=6 x=60)$. One species ( $K$ rupicola) was found to possess two ploidy levels. In $K$. foreziensis (Fig. 1f) an additional chromosome was observed, which likely represents a Bchromosome but more detailed analyses have to be performed to exclude aneuploidy. Cut-out karyotypes were prepared for six individuals representing six species, three of which are diploid, two tetraploid and one hexaploid (Additional file 1: Figure S1). The karyotypes cannot be directly compared as it is impossible to define homo- or homeologous chromosome pairs based on chromosome morphology alone. Karyotypes of diploid species are composed mostly of meta-, submeta- to acrocentric chromosomes, one or two of which carry visible NOR regions, usually as subterminal satellites (Additional file 1: Figure S1). Polyploids have similar types of karyotypes, but the low number of chromosome 
Table 1 Summary results of flow cytometric analyses in Knautia, using DAPI (relative DNA content, given in arbitrary units) and PI (absolute DNA content, given in pg) fluorochromes as well as the determined chromosome number

\begin{tabular}{|c|c|c|c|c|c|c|c|c|c|}
\hline Taxon & Section & $\begin{array}{l}\text { Estimated } \\
\text { ploidy level }\end{array}$ & $\begin{array}{l}\text { Relative genome } \\
\text { size (mean) }\end{array}$ & $\begin{array}{l}\text { Intracytotype } \\
\text { variation, } \\
\text { max/min (\%) }\end{array}$ & $\begin{array}{l}\text { Mean monoploid } \\
\text { relative genome size }\end{array}$ & $\begin{array}{l}\text { RGS N measured } \\
\text { individuals/ } \\
\text { populations }\end{array}$ & $\begin{array}{l}\text { Absolute genome } \\
\text { size (pg) }\end{array}$ & $\begin{array}{l}\text { AGS N measured } \\
\text { individuals/ } \\
\text { populations }\end{array}$ & $\begin{array}{l}\text { Chromosome } \\
\text { number (ID) }\end{array}$ \\
\hline K. adriatica Ehrend. & Trichera & $4 x$ & 0.579 & & 0.145 & $5 / 1$ & & & \\
\hline K. albanica Briq. & Trichera & $2 x$ & $0.286-0.291(0.288)$ & 1.75 & 0.144 & $20 / 2$ & $7.26-7.64$ & $2 / 1$ & \\
\hline K. ambigua Boiss. \& Orph & Trichera & $2 x$ & $0.279-0.300(0.292)$ & 7.53 & 0.146 & $32 / 7$ & & & \\
\hline \multirow[t]{2}{*}{ K. arvensis (L.) Coult. } & Trichera & $2 x$ & $0.277-0.305(0.291)$ & 10.11 & 0.145 & $184 / 33$ & & & \\
\hline & & $4 x$ & $0.551-0.585(0.567)$ & 6.17 & 0.142 & $68 / 14$ & $13.93-14.11$ & $2 / 1$ & $40(K 455)$ \\
\hline K. arvensis $\times$ kitaibelii & Trichera & $4 x$ & $0.546-0.587(0.566)$ & 7.51 & 0.142 & $10 / 2$ & & & \\
\hline K. arvernensis (Briq.) Szabó & Trichera & $4 x$ & $0.575-0.595(0.586)$ & 3.48 & 0.147 & $30 / 6$ & $14.84-15.15$ & $4 / 2$ & 40 (K387) \\
\hline K. baldensis Kern. \& Szabó & Trichera & $4 x$ & $0.550-0.563(0.556)$ & 2.36 & 0.140 & $32 / 5$ & $14.36-14.79$ & $2 / 1$ & \\
\hline K. basaltica Chass. \& Szabó & Trichera & $2 x$ & $0.306-0.309(0.308)$ & 0.98 & 0.154 & $10 / 2$ & $7.51-7.72$ & $4 / 2$ & 20 (K386) \\
\hline K. calycina (Presl) Guss. & Trichera & $2 x$ & $0.305-0.341(0.318)$ & 11.80 & 0.159 & $111 / 14$ & $8.00-8.29$ & $2 / 1$ & 20 (K323) \\
\hline K. carinthiaca Ehrend. & Trichera & $2 x$ & $0.269-0.276(0.273)$ & 2.60 & 0.137 & $20 / 2$ & & & \\
\hline \multirow[t]{2}{*}{ K. clementii (Beck) Ehrend. } & Trichera & $4 x$ & $0.528-0.547(0.540)$ & 3.60 & 0.135 & $20 / 3$ & 14.64 & $1 / 1$ & \\
\hline & Trichera & $6 x$ & 0.761 & & 0.127 & $5 / 1$ & & & \\
\hline K. collina (Req. ex Guérin) Jord. & Trichera & $2 x$ & $0.279-0.336(0.323)$ & 20.43 & 0.162 & $36 / 8$ & $8.58-8.80$ & $4 / 2$ & 20 (K414) \\
\hline K. csikii Jáv. \& Szabó & Trichera & $2 x$ & $0.282-0.293(0.287)$ & 3.90 & 0.144 & $10 / 2$ & & & \\
\hline K. dalmatica Beck & Trichera & $4 x$ & $0,551^{*}$ & & $0.138^{*}$ & $5 / 1$ & & & \\
\hline K. cf degenii Borbás & Tricheroides & $2 x$ & $0.242-0.244(0.243)$ & 0.83 & 0.122 & $7 / 2$ & & & \\
\hline \multirow[t]{2}{*}{ K. dinarica K. Malý } & Trichera & $2 x$ & $0.258-0.283(0.267)$ & 9.69 & 0.134 & $62 / 9$ & & & \\
\hline & & $4 x$ & $0.494-0.58(0.536)$ & 17.41 & 0.135 & $112 / 16$ & $13.57-14.11$ & $5 / 4$ & \\
\hline \multirow[t]{2}{*}{ K. dipsacifolia Kreutz. } & Trichera & $4 x$ & $0.522-0.56(0.537)$ & 7.28 & 0.134 & $25 / 3$ & & & \\
\hline & & $6 x$ & $0.782-0.856(0.824)$ & 9.46 & 0.137 & $77 / 11$ & $20.81-21.57$ & $4 / 2$ & 60 (K029) \\
\hline \multirow[t]{2}{*}{ K. drymeia Heuff. } & Trichera & $2 x$ & $0.251-0.303(0.281)$ & 20.72 & 0.141 & $136 / 25$ & $7.27-7.44$ & $6 / 4$ & 20 (K312) \\
\hline & & $4 x$ & $0.495-0.582(0.547)$ & 17.58 & 0.137 & $198 / 39$ & & & \\
\hline $\begin{array}{l}\text { K. fleischmannii (Hladn. } \\
\text { ex Rchb.) Pach. }\end{array}$ & Trichera & $4 x$ & 0.583 & & 0.146 & $10 / 1$ & & & \\
\hline K. foreziensis Chass. \& Szabó & Trichera & $4 x$ & 0.596 & & 0.149 & $9 / 2$ & $14.80-15.30$ & $2 / 1$ & $40+1 B(K 380)$ \\
\hline K. godetii Reut. & Trichera & $2 x$ & $0.296-0.303(0.299)$ & 2.36 & 0.150 & $15 / 3$ & & & \\
\hline \multirow[t]{3}{*}{ K. illyrica Beck } & Trichera & $2 x$ & $0.286-0.298(0.292)$ & 4.20 & 0.146 & $25 / 3$ & & & \\
\hline & & $4 x$ & $0.554-0.593(0.573)$ & 7.04 & 0.143 & $40 / 6$ & & & \\
\hline & & $6 x$ & 0.877 & & 0.146 & $10 / 1$ & $21.13-21.25$ & $2 / 1$ & 60 (K045) \\
\hline
\end{tabular}


Table 1 Summary results of flow cytometric analyses in Knautia, using DAPI (relative DNA content, given in arbitrary units) and PI (absolute DNA content, given in pg) fluorochromes as well as the determined chromosome number (Continued)

\begin{tabular}{|c|c|c|c|c|c|c|c|c|c|}
\hline Taxon & Section & $\begin{array}{l}\text { Estimated } \\
\text { ploidy level }\end{array}$ & $\begin{array}{l}\text { Relative genome } \\
\text { size (mean) }\end{array}$ & $\begin{array}{l}\text { Intracytotype } \\
\text { variation, } \\
\text { max/min (\%) }\end{array}$ & $\begin{array}{l}\text { Mean monoploid } \\
\text { relative genome size }\end{array}$ & $\begin{array}{l}\text { RGS N measured } \\
\text { individuals/ } \\
\text { populations }\end{array}$ & $\begin{array}{l}\text { Absolute genome } \\
\text { size (pg) }\end{array}$ & $\begin{array}{l}\text { AGS N measured } \\
\text { individuals/ } \\
\text { populations }\end{array}$ & $\begin{array}{l}\text { Chromosome } \\
\text { number (ID) }\end{array}$ \\
\hline K. integrifolia (L.) Bertol. & Tricheroides & $2 x$ & $0.120-0.192(0.164)$ & 60.00 & 0.082 & $109 / 21$ & $3.90-4.11$ & $2 / 1$ & \\
\hline $\begin{array}{l}\text { K. involucrata Sommier \& } \\
\text { Levier }\end{array}$ & Trichera & $2 x$ & 0.36 & & 0.180 & $5 / 1$ & & & \\
\hline K. kitaibelii (Schult.) Borb. & Trichera & $4 x$ & $0.531-0.554(0.543)$ & 4.33 & 0.136 & $6 / 2$ & & & \\
\hline K. lebrunii J. Prudhomme & Trichera & $2 x$ & $0.301-0.306(0.304)$ & 1.66 & 0.152 & $10 / 2$ & $7.86-8.08$ & $3 / 2$ & \\
\hline K. legionensis DC. & Trichera & $4 x$ & $0.633-0.643(0.637)$ & 1.58 & 0.159 & $15 / 3$ & $16.26-16.76$ & $4 / 2$ & \\
\hline $\begin{array}{l}\text { K. longifolia (Waldst. \& Kit.) } \\
\text { Koch }\end{array}$ & Trichera & $2 x$ & $0.268-0.293(0.281)$ & 9.33 & 0.141 & $68 / 7$ & $7.05-7.24$ & $5 / 3$ & \\
\hline K. lucana Lacaita \& Szabó & Trichera & $2 x$ & 0.31 & & 0.155 & $9 / 1$ & 7.57 & $1 / 1$ & \\
\hline K. macedonica Griseb. & Trichera & $2 x$ & $0.281-0.295(0.290)$ & 4.98 & 0.145 & $18 / 3$ & & & \\
\hline K. magnifica Boiss. \& Orph. & Trichera & $4 x$ & $0.505-0.551(0.524)$ & 9.11 & 0.131 & $28 / 4$ & & & \\
\hline \multirow[t]{2}{*}{ K. midzorensis Form. } & Trichera & $2 x$ & $0.276-0.281(0.279)$ & 1.81 & 0.140 & $20 / 3$ & & & \\
\hline & & $4 x$ & $0.500-0.544(0.527)$ & 8.80 & 0.132 & $41 / 8$ & & & \\
\hline K. mollis Jord. & Trichera & $2 x$ & $0.328-0.330(0.329)$ & 0.61 & 0.165 & $10 / 2$ & $8.23-8.58$ & $4 / 2$ & 20 (K373) \\
\hline K. montana (Bieb.) D.C. & Trichera & $2 x$ & $0.332-0.360(0.344)$ & 8.43 & 0.172 & $18 / 4$ & & & \\
\hline K. nevadensis Szabó & Trichera & $4 x$ & $0.600-0.645(0.624)$ & 7.50 & 0.156 & $20 / 4$ & $15.65-16.92$ & $3 / 2$ & $\begin{array}{l}40(\mathrm{~K} 405 \\
\mathrm{K} 406)\end{array}$ \\
\hline K. norica Ehrend. & Trichera & $4 x$ & $0.540-0.549(0.545)$ & 1.67 & 0.136 & $23 / 4$ & & & \\
\hline K. orientalis $\mathrm{L}$. & Knautia & $2 x$ & $0.353-0.368(0.360)$ & 4.25 & 0.180 & $20 / 4$ & & & \\
\hline K. pancicii Szabó & Trichera & $2 x$ & 0.273 & & 0.137 & $9 / 1$ & & & \\
\hline \multirow[t]{2}{*}{ K. pectinata Ehrend. } & Trichera & $2 x$ & 0.288 & & 0.144 & $10 / 1$ & & & \\
\hline & & $4 x$ & $0.556-0.586(0.570)$ & 5.40 & 0.143 & $30 / 4$ & 15.00 & $1 / 1$ & 40 (K100) \\
\hline K. persicina Kern. & Trichera & $4 x$ & $0.562-0.582(0.572)$ & 3.56 & 0.143 & $20 / 2$ & $14.87-15.54$ & $2 / 1$ & \\
\hline \multirow[t]{2}{*}{ K. purpurea (Vill.) Borb. } & Trichera & $2 x$ & $0.299-0.312(0.305)$ & 4.35 & 0.153 & $20 / 3$ & $7.70-8.59$ & $4 / 2$ & \\
\hline & & $4 x$ & $0.576-0.577(0.576)$ & 0.17 & 0.144 & $15 / 2$ & & & \\
\hline K. ressmannii (Pach.) Briq. & Trichera & $6 x$ & $0.841-0.866(0.851)$ & 2.97 & 0.142 & $12 / 3$ & $21.49-21.67$ & $4 / 3$ & $\begin{array}{l}60(\mathrm{~K} 448, \\
\mathrm{K} 450)\end{array}$ \\
\hline \multirow[t]{2}{*}{ K. rupicola (Willk.) Font Quer } & Trichera & $4 x$ & 0,730 & & 0.183 & $5 / 1$ & 23.09 & $1 / 1$ & $40(K 400)$ \\
\hline & Trichera & $6 x$ & $1.057-1.063(1.060)$ & 0.57 & 0.177 & $6 / 2$ & $25.49-26.33$ & $2 / 1$ & 60 (K402) \\
\hline K. sarajevensis Szabó & Trichera & $4 x$ & $0.465-0.544(0.513)$ & 16.99 & 0.128 & $65 / 8$ & $13.66-13.78$ & $2 / 1$ & \\
\hline K. slovaca Stepanek & Trichera & $2 x$ & $0.280-0.292(0.286)$ & 4.29 & 0.143 & $7 / 3$ & & & \\
\hline
\end{tabular}


Table 1 Summary results of flow cytometric analyses in Knautia, using DAPI (relative DNA content, given in arbitrary units) and PI (absolute DNA content, given in pg) fluorochromes as well as the determined chromosome number (Continued)

\begin{tabular}{|c|c|c|c|c|c|c|c|c|c|}
\hline Taxon & Section & $\begin{array}{l}\text { Estimated } \\
\text { ploidy level }\end{array}$ & $\begin{array}{l}\text { Relative genome } \\
\text { size (mean) }\end{array}$ & $\begin{array}{l}\text { Intracytotype } \\
\text { variation, } \\
\text { max/min (\%) }\end{array}$ & $\begin{array}{l}\text { Mean monoploid } \\
\text { relative genome size }\end{array}$ & $\begin{array}{l}\text { RGS N measured } \\
\text { individuals/ } \\
\text { populations }\end{array}$ & $\begin{array}{l}\text { Absolute genome } \\
\text { size (pg) }\end{array}$ & $\begin{array}{l}\text { AGS N measured } \\
\text { individuals/ } \\
\text { populations }\end{array}$ & $\begin{array}{l}\text { Chromosome } \\
\text { number (ID) }\end{array}$ \\
\hline \multirow[t]{2}{*}{ K. subcanescens Jord. } & Trichera & $2 x$ & $0.288-0.290(0.289)$ & 0.69 & 0.145 & $10 / 2$ & $7.44-7.61$ & $3 / 2$ & \\
\hline & Trichera & $4 x$ & 0.582 & & 0.146 & $5 / 1$ & & & \\
\hline K. subscaposa Boiss. \& Reut. & Trichera & $2 x$ & $0.411-0.424(0.417)$ & 3.16 & 0.209 & $28 / 6$ & & & \\
\hline \multirow[t]{3}{*}{ K. travnicensis Beck } & Trichera & $2 x$ & $0.263-0.296(0.282)$ & 12.55 & 0.141 & $13 / 3$ & & & \\
\hline & & $4 x$ & 0.526 & & 0.132 & $10 / 1$ & & & \\
\hline & & $6 x$ & $0.759-0.802(0.778)$ & 5.67 & 0.130 & $29 / 4$ & & & \\
\hline K. velebitica Szabó & Trichera & $2 x$ & $0.296-0.318(0.307)$ & 7.43 & 0.154 & $35 / 4$ & 7.49 & $1 / 1$ & \\
\hline K. velutina Briq. & Trichera & $2 x$ & $0.292-0.309(0.302)$ & 5.82 & 0.151 & $40 / 6$ & $7.61-7.81$ & $2 / 1$ & \\
\hline K. visianii Szabó & Trichera & $2 x$ & $0.285-0.304(0.293)$ & 6.67 & 0.147 & $87 / 13$ & 7.29-7.61 & $4 / 2$ & \\
\hline K. wagneri Briq. & Trichera & $4 x$ & 0.488 & & 0.122 & $3 / 1$ & & & \\
\hline K. sp.1 & Trichera & $6 x$ & $0.775-0.828(0.796)$ & 6.84 & 0.133 & $32 / 4$ & & & \\
\hline K. sp.2 & Trichera & $4 x$ & 0.51 & & 0.128 & $5 / 1$ & & & \\
\hline
\end{tabular}

* samples with low quality of RGS, used only to determine ploidy level but not included in statistical analyses 

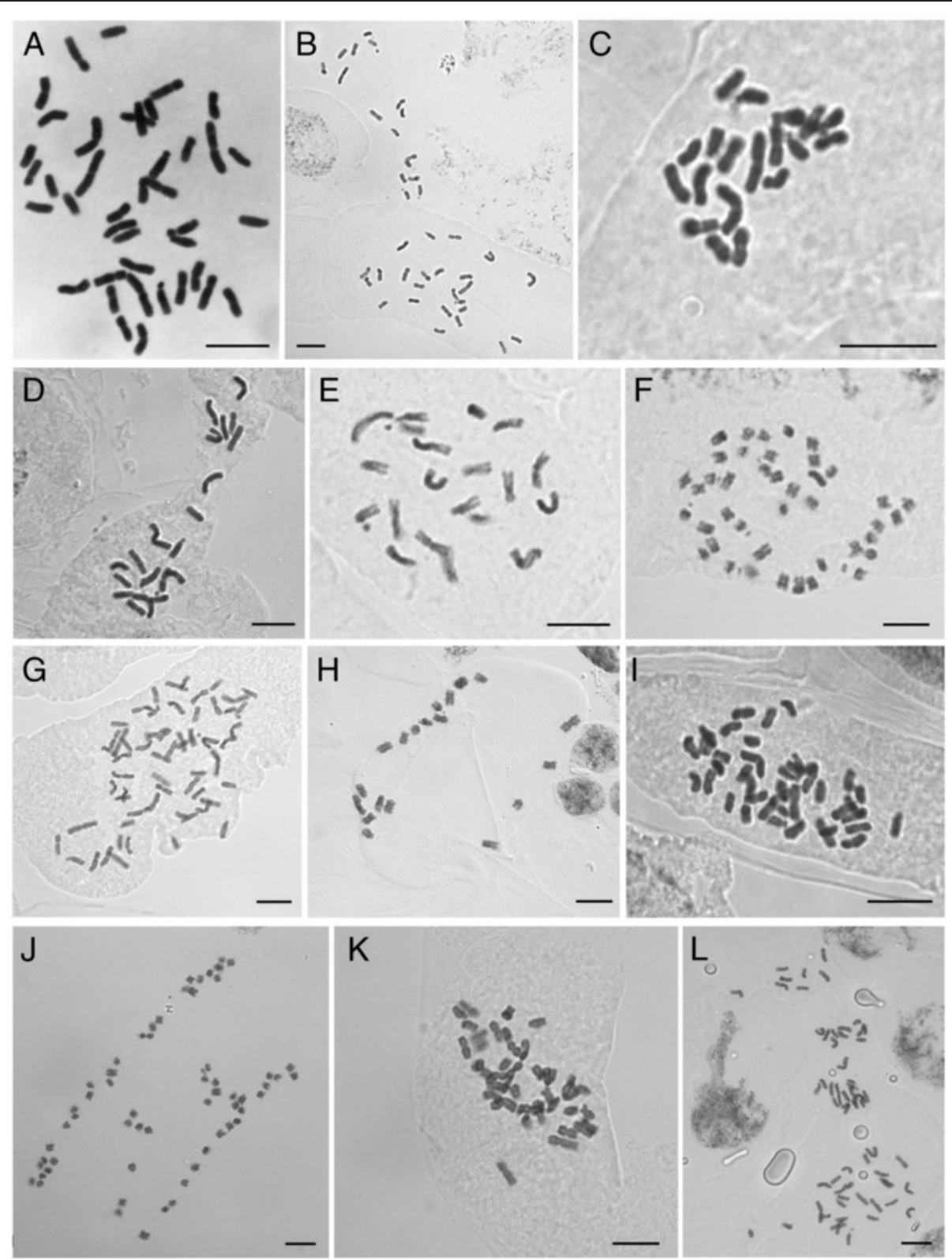

Fig. 1 Mitotic chromosomes of Knautia species. a $K$. arvensis $K 455,2 n=4 x=40$. b $K$. arvernensis $K 387,2 n=4 x=40$. c $K$. basaltica K386, $2 n=2 x=20$. $\mathbf{d} K$. collina K414, $2 n=2 x=20$. e $K$. drymeia $K 312,2 n=2 x=20$. f $K$. foreziensis K380, $2 n=4 x=40+1 B$. g K. illyrica K045, $2 n=6 x=60$. h $K$. mollis K373, $2 n=2 x=20$. i K. nevadensis $K 406,2 n=4 x=40$. j K. ressmannii K450, $2 n=6 x=60$. $\mathbf{K}$ K. rupicola K400, $2 n=4 x=40 . \mathbf{I}$ K. rupicola $K 402,2 n=6 x=60$. Details for the sampling localities are given in the Additional file 2: Table S1

slides available to prepare karyotypes prevented direct comparisons.

\section{Flow cytometry and estimations of DNA-ploidy levels}

Relative DNA content (RGS) was measured in 2253 individuals from 381 populations of 54 Knautia species, and absolute genome size (AGS) was determined for 88 individuals from 52 populations of 30 species (Table 1 , Additional file 2: Table S1). In nine populations RGS measurements were of low quality ( $\mathrm{CV}$ exceeding the threshold of $5 \%$ ) and were thus excluded from the statistical analyses and only used for ploidy level determination. The cytometrically determined ploidy level corresponded to the estimated chromosome numbers in all karyologically analysed samples.

The correlation between mean AGS and RGS obtained from the same populations was high across the whole GS range $(\mathrm{r}=0.969, p=0.01)$ and across diploids and tetraploids (diploids $\mathrm{r}=0.858$; tetraploids $\mathrm{r}=0.729$; $p=0.000)$, but not hexaploids $(\mathrm{r}=0.536, p=0.215)$, 
which is likely explained by the fact that AGS was determined for only 12 hexaploid individuals. The RGS ranged from 0.120 in diploid $K$. integrifolia (K226) to 1.063 in hexaploid $K$. rupicola (K402), exhibiting 8.86fold variation (Table 1, Fig. 2), whereas the AGS varied between $3.90 \mathrm{pg}$ in $K$. integrifolia (K314) and $26.33 \mathrm{pg}$ in K. rupicola (K402), exhibiting 6.75-fold variation. According to RGS all analysed populations were separated into three ploidy levels (only populations with a single ploidy level were observed): DNA-diploids (52.6\%), DNA-tetraploids (40.5 \%), and DNA-hexaploids (6.9\%). We use the prefix 'DNA-' in order to acknowledge that for most populations analysed no chromosome counts are available [47]. For simplicity, the prefix is omitted hereafter.

Forty-two out of 54 analysed taxa $(77.8 \%)$ possessed only one ploidy level, of which $57.1 \%$ were diploids, $38.1 \%$ tetraploids and $4.8 \%$ hexaploids. Ten taxa (18.5\%) had two ploidy levels, of these $70 \%$ were di-/tetraploids and $30 \%$ tetra-/hexaploids. Two taxa (3.7\%), i.e. K. illyrica and K. travnicensis, contained all three ploidy levels. The mean RGS differed significantly between any two ploidy levels (Kruskal-Wallis test followed by Mann-Whitney pairwise comparison and Bonferroni corrections of p values; Fig. 3). Diploid populations also differed significantly from tetraploids and hexaploids in monoploid RGS, whereas there was no significant difference between tetraploids and hexaploids (Fig. 3). The same results were obtained after the exclusion of the Iberian taxa K. legionensis, $K$. nevadensis, $K$. rupicola and K. subscaposa with clearly higher monoploid RGS. Intraploidy variation in RGS was relatively large in all three ploidy levels in section Trichera (1.69-fold variation in diploids, 1.57 -fold variation in tetraploids, 1.40 -fold variation in hexaploids). The highest intraspecific RGS variation within a ploidy level was observed in $K$. integrifolia from sect. Tricheroides (1.60-fold variation); in sect. Trichera the highest variation was in diploid $K$. drymeia (1.21-fold variation). Intraspecific intra-cytotype variation was confirmed with simultaneous analyses of samples with different RGS, yielding histograms with one bifurcate (Fig. 4a) or two separate peaks (Figs. 4b, 4c).

\section{Evolution of RGS in Knautia}

Reconstruction of RGS evolution on the combined ITS and plastid phylogeny revealed a gradual increase of RGS along the branch leading to sect. Knautia and a decrease along the branch of sect. Tricheroides (Fig. 5). No such trends were observed along the branch leading to sect Trichera, but within this section both increasing and decreasing RGS were observed, the most striking being the increase along the branch leading to Iberian K. subscaposa with strongly deviating GS (Fig. 5b). The estimate of $\lambda$ was 0.999 , indicating that RGS exhibits a strong phylogenetic signal in Knautia, which was also confirmed by a Chi-square test.

\section{Distribution patterns of cytotypes and GS variants in sect. Trichera}

Diploid and tetraploid populations of different species occur across most of the distribution area of Knautia, whereas hexaploid populations exhibit a more restricted distribution in the Balkans (central Dinaric Mountains), the Alps (extra-Alpine populations of $K$. dipsacifolia were not sampled) and the Iberian Peninsula (two populations of $K$. rupicola in eastern Spain; Figs. 6, 7). The monoploid

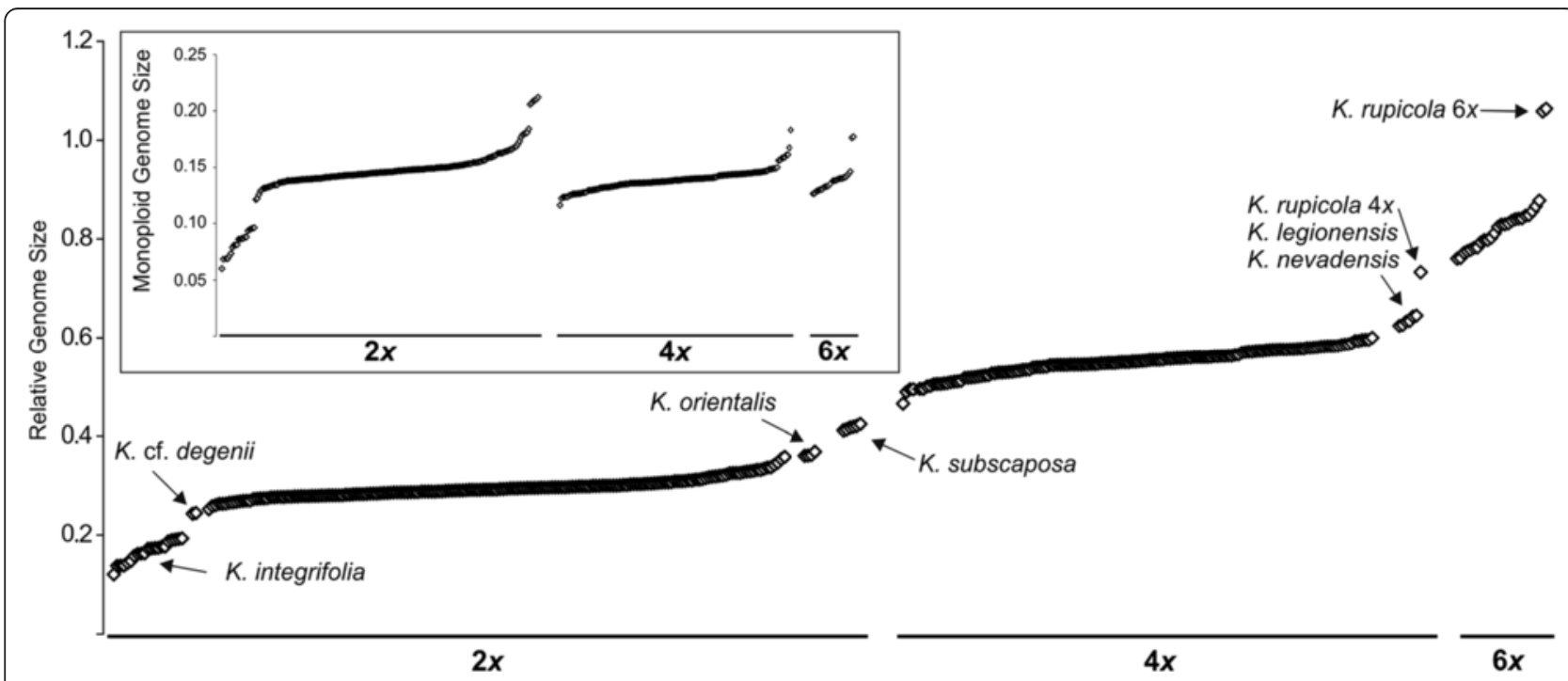

Fig. 2 Genome size variation in Knautia: relative genome size, monoploid relative genome size (insert). Taxa mentioned in the Discussion are indicated 

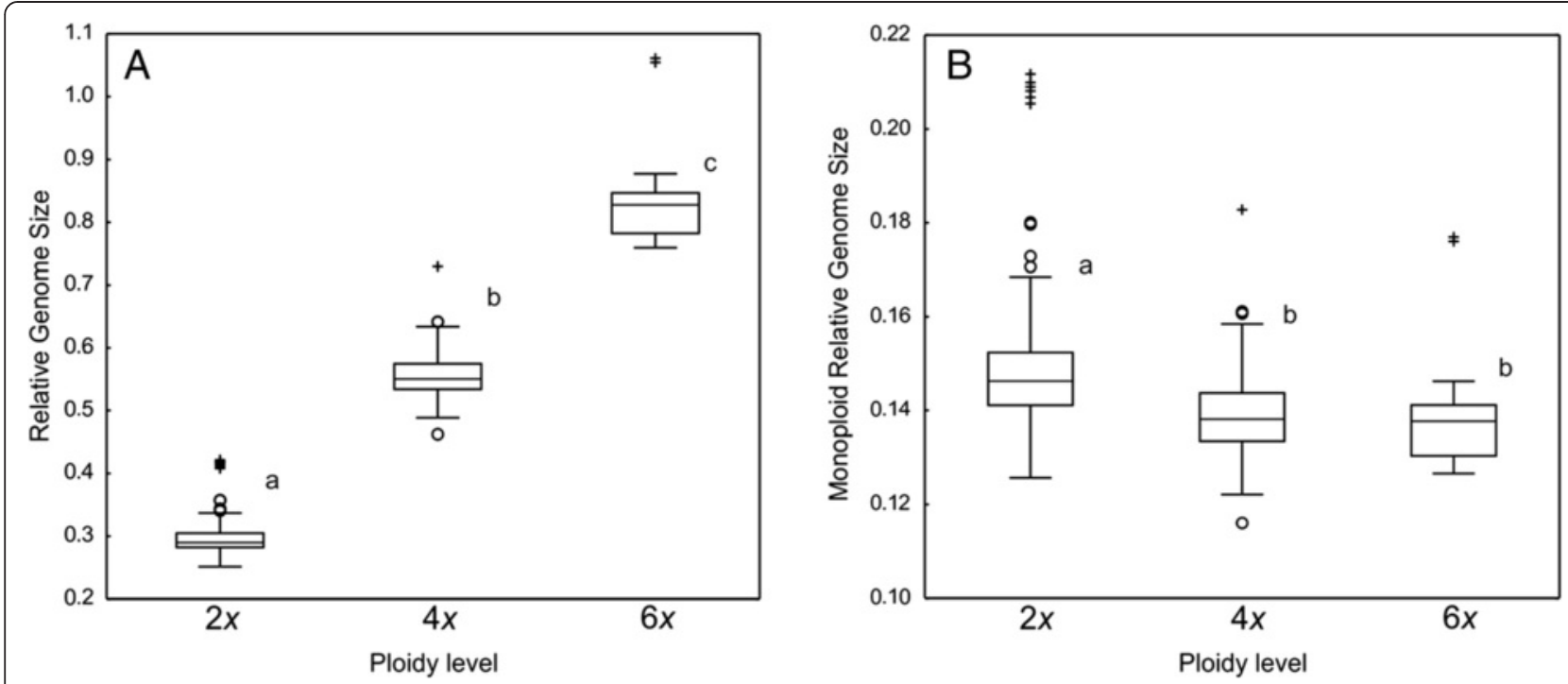

Fig. 3 Relative genome size (a) and monoploid relative genome size (b) of cytotypes in Knautia sect. Trichera. Boxes define 25 and 75 percentiles; horizontal lines indicate medians, whiskers are from 5 to 95 percentiles, circles indicate outliers and crosses extreme values (outside the 3 box length range from the upper and lower value of the box). Means not significantly different at $P \leq 0.01$ are indicated by the same letter (Kruskal-Wallis test followed by Mann-Whitney pairwise comparisons and Bonferroni corrections of $\mathrm{p}$ values)

RGS of di- and tetraploid individuals is smaller in the western Balkan Peninsula and the Alps and increases towards the eastern, western and southern margins of the genus' distribution area in diploids, and towards the western and northern margins in tetraploids and hexaploids $\left(\mathrm{r}_{\mathrm{s}}=0.405, \mathrm{r}_{\mathrm{s}}=0.656\right.$, and $\mathrm{r}_{\mathrm{s}}=0.671 p<0.01$ for diploids, tetraploids and hexaploids, respectively; Fig. 7).

Among the widely distributed heteroploid species (i.e., species with different ploidy levels) only $K$. dinarica, $K$. drymeia, K. dipsacifolia, and to some extent $K$. arvensis exhibit geographic patterns of cytotype distributions. (1) The northern populations of $K$. dinarica are diploid, the southern tetraploid; (2) diploid $K$. drymeia is restricted to the west and the east of the total distribution area, whereas tetraploids occur in intermittent areas and north of the diploids; (3) hexaploid $K$. dipsacifolia is limited to the Alps, whereas tetraploids occur in the Carpathians and the Balkans, (4) diploids of $K$. arvensis are mostly distributed in the inner part of the Alpine arch, whereas tetraploids extend from its outer margin towards the northeast and southeast (Fig. 6).

\section{Discussion}

It has been acknowledged that polyploidisation has played an important role in the diversification of Knautia sect. Trichera [12, 35, 36, 42, 44, 45], but our comprehensive taxonomic and geographic sampling provides unprecedented resolution and reveals patterns not documented previously.

\section{Ploidy levels and chromosome numbers in Knautia}

GS measurements with confirmatory chromosome numbers (Table 1, Figs. 1, 2, 3, 6) reveal the presence of three even ploidy levels (diploid, tetraploid and hexaploid) in Knautia. Minority odd ploidies (triploid, pentaploid), occasionally documented in this genus [12], were not observed in the present study. The RGS values are discretely distributed in three ranges (Figs. 2-3), fully correlated with chromosome numbers counts for 14 taxa (Fig. 1) and correspond to three ploidy levels (Table 1). The only exceptions are the Iberian taxa $K$. legionensis, $K$. nevadensis, K. rupicola and $K$. subscaposa, which have deviating GS (see below; Figs. 2 \& 7), but their ploidy level was confirmed by chromosome numbers counted for $K$. rupicola (Fig. 1). Thus, the GS is a reliable indicator of ploidy level in Knautia. A similar correlation has been reported for other genera [13, 16, 48-50], but was not observed in Cerastium [14] or some species in Orobanchaceae [51].

In accordance with previous evidence $[35,36,42]$ a high level of ploidy diversity was observed within sect. Trichera, whereas all members of the species-poor sections Tricheroides and Knautia are diploid [35]. Among 51 investigated taxa from sect. Trichera, 39 taxa (76.5 \%) had a single ploidy level (diploid, tetraploid or hexaploid), ten taxa (19.6\%) had two ploidy levels (seven taxa with diploid and tetraploid cytotypes, three taxa with tetraploid and hexaploid cytotypes), and two taxa (3.9\%) included all three cytotypes (Table 1, Fig. 2). Chromosome numbers for $K$. rupicola $(2 n=4 x=40$ and 

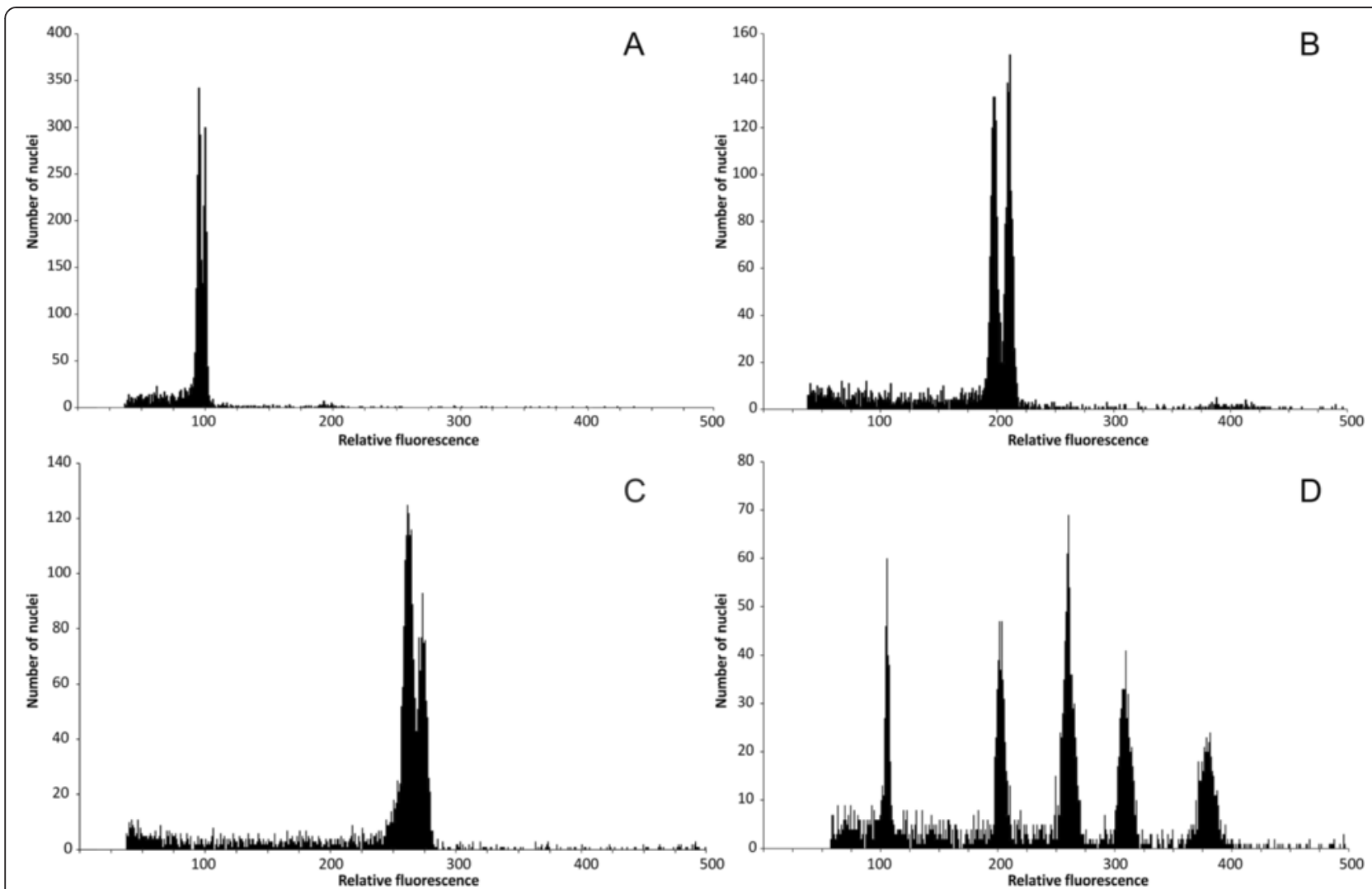

Fig. 4 Flow cytometry histograms showing genuine differences in relative genome size. Histograms showing differences within ploidy levels of Knautia (a-b) and the divergent relative genome size of the Iberian taxa, exemplified by tetra- and hexaploid K. rupicola (d). a diploid Knautia drymeia (K040, right) and K. lebrunii (K408, left). b Tetraploid K. nevadensis (K405, right, and K406, left). c Hexaploid K. dipsacifolia (K029, right, and K038, left). d From left to right: diploid K. drymeia (K039), tetraploid K. dinarica (K028) and K. rupicola (K400), hexaploid K. ressmannii (K449) and K. rupicola (K402)

$2 n=6 x=60$; Table 1), were obtained for the first time [52] and include the only hexaploid cytotype of Knautia known from the Iberian Peninsula. The same applies to the chromosome numbers for hexaploid $K$. illyrica $(2 n$ $=6 x=60$; previously considered exclusively tetraploid) and for tetraploid $K$. pectinata $(2 n=4 x=40$; previously considered exclusively diploid) (Table 1). Additionally, RGS data revealed the presence of diploidy in K. csikii, $K$. cf. degenii, K. involucrata, K. lucana, K. macedonica and $K$. pancicii, and tetraploidy in $K$. legionensis and $K$. wagneri, whose ploidy levels were previously unknown. Furthermore, in several taxa new cytotypes were found: diploids in K. subcanescens (previously considered uniformly tetraploid), diploids and tetraploids in K. travnicensis (considered hexaploid), diploids and hexaploids in $K$. illyrica (considered tetraploid) and hexaploids in K. clementii (considered tetraploid). On the other hand, some previously recorded cytotypes were not observed: we found only diploid populations of $K$. collina, but no tetraploids as recorded by Devesa [52], and only tetraploid but no hexaploid $K$. nevadensis. In accordance with
Devesa [52] we consider the report of $2 n=6 x=64$ by Ehrendorfer [35] erroneous. In $K$. dalmatica we discovered only one tetraploid population, although previous data suggested diploidy [40]. Taking the cytotype diversity of several taxa into account, the failure to confirm previously recorded ploidy levels in the abovementioned taxa is likely caused by the still limited number of investigated populations of these species. Alternatively, bearing in mind morphological variability and similarity of several species, some of the previously observed cytotypes might refer to different, misidentified species.

\section{Cytotype distribution patterns}

Diploids and tetraploids are widespread throughout the distribution area of the genus (except for the eastern edge, where only diploids occur; Fig. 6), whereas hexaploids are restricted to the Alps ( $K$. dipsacifolia, $K$. illyrica and $K$. ressmannii), the central Dinaric Mountains (K. clementii, K. travnicensis and $K$. sp. 1 ) and eastern Spain ( $K$. rupicola). Hexaploid $K$. dipsacifolia 


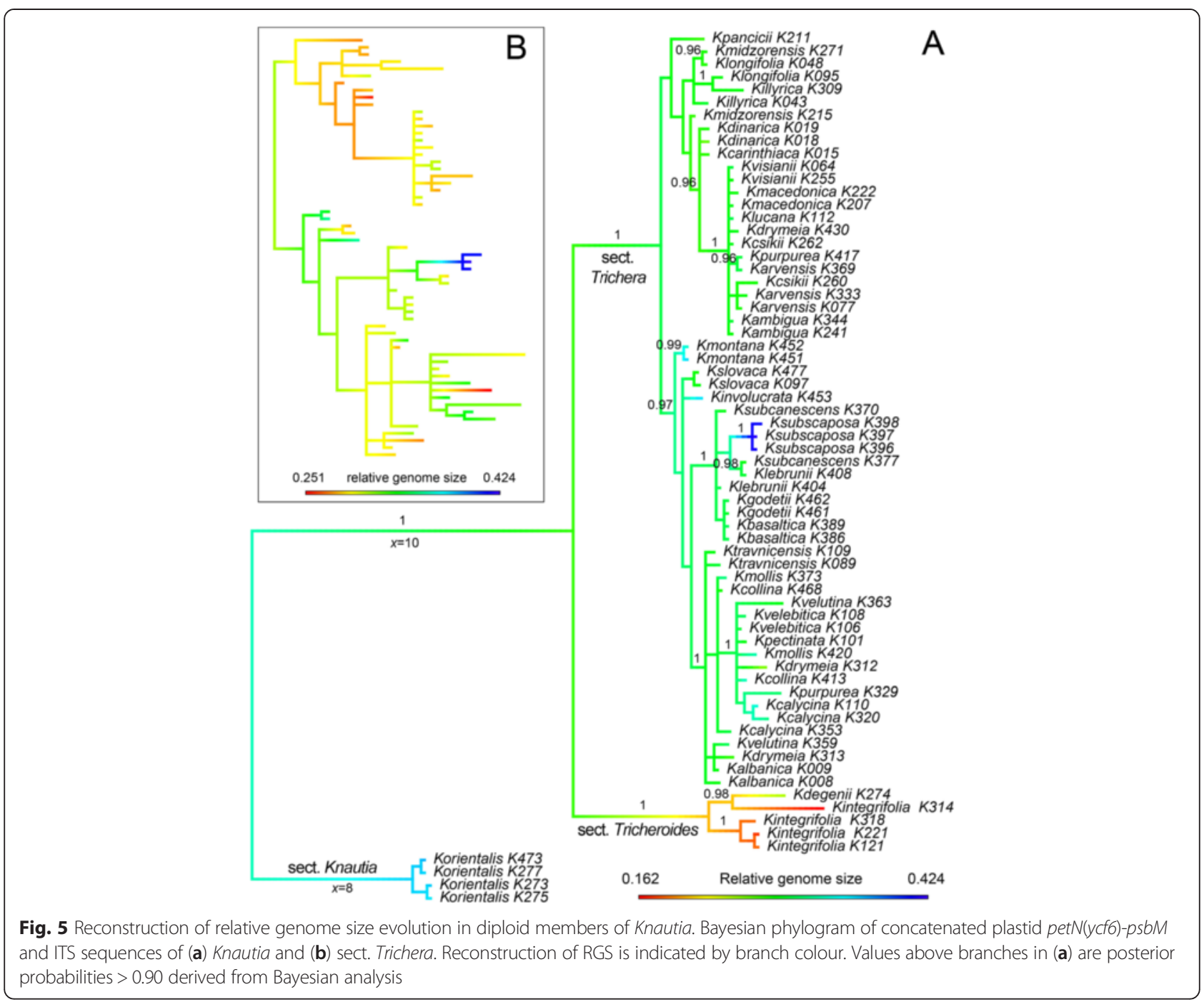

occurs also north of the Alps [36], but those populations were not included in our study. Overall spatial patterns and phylogenetic data (Frajman et al., unpubl. res.) suggest that tetraploids arose independently within almost all lineages of sect. Trichera, whereas hexaploids originated at least four times.

Among the widely distributed heteroploid species only $K$. dinarica, $K$. drymeia and $K$. dipsacifolia, and to some extent $K$. arvensis, exhibit geographic patterns of cytotype distributions. The northern populations of $K$. dinarica from the central Dinaric Mountains are diploid, whereas the populations in the southern Dinaric Mountains are tetraploid (Fig. 6). This is in accordance with Ehrendorfer [35], who, however, investigated only three populations. The contact zone between di- and tetraploids is approximately along the Sutjeska river valley, which was also identified as a major phylogeographic break in the Heliosperma pusillum group [53]. A similar pattern is observed on the Apennine Peninsula where the disjunct populations of $K$. dinarica subsp. silana from the southern Apennines are tetraploid, while the population from the central Apennines is diploid, suggesting connections with Balkan populations [54]. Amphiadriatic distributions are documented in several plant [55] and animal [56] species and are usually explained by land bridges across the Adriatic Sea during the Messinian salinity crisis (Miocene/Pliocene) or during Pleistocene glaciations $[56,57]$. The diversification of sect. Trichera likely took place in the Pliocene/Pleistocene rendering Pleistocene migration more likely, but molecular dating analyses are needed to corroborate this hypothesis (Frajman et al., unpubl. res.).

A similar amphiadriatic connection can be observed in $K$. drymeia. In this species diploids can be found only in the west (Italy and Slovenia) and east (Bulgaria, Macedonia, 


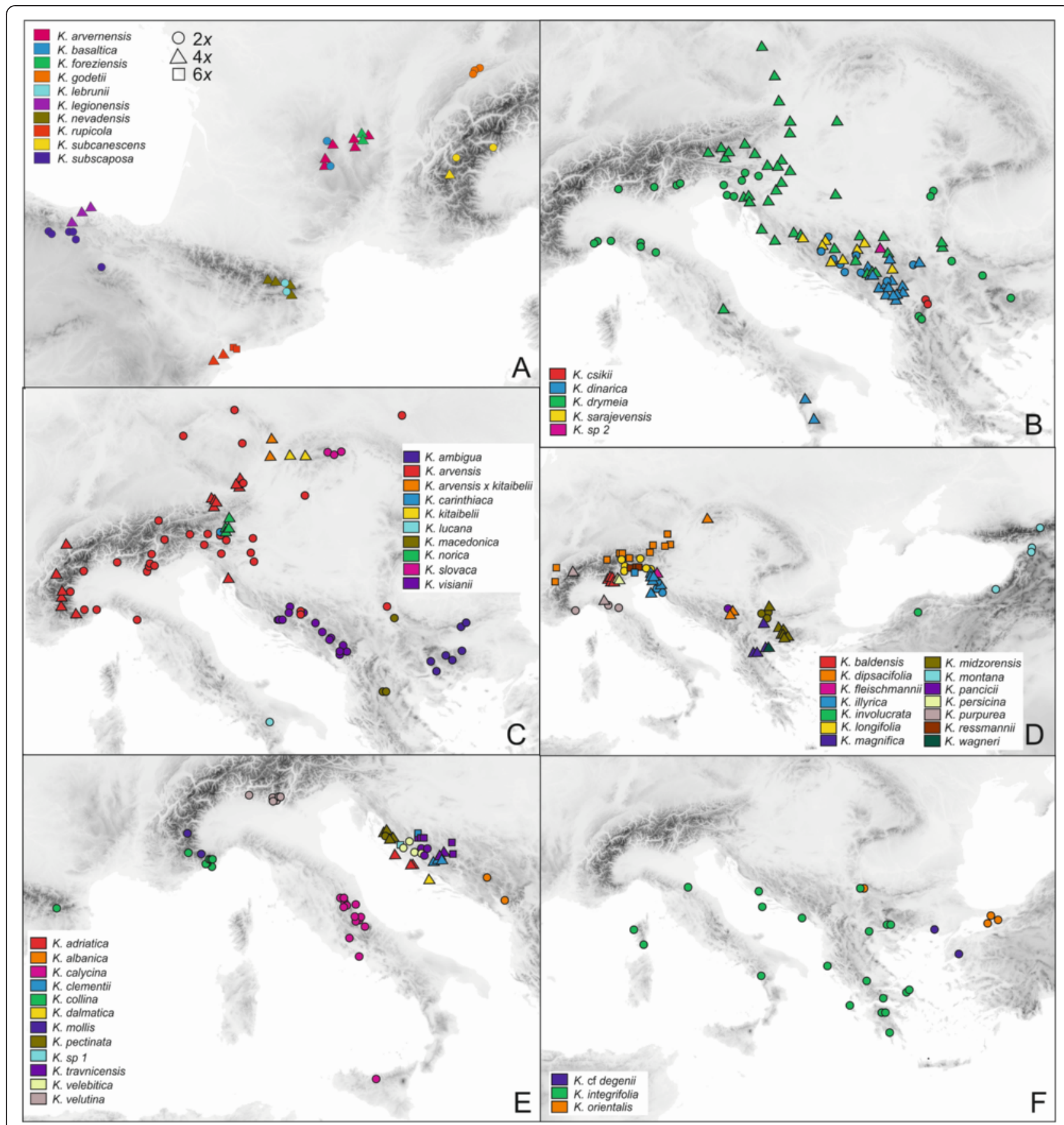

Fig. 6 Geographical distribution of cytotypes in the genus Knautia. Circles: diploids; triangles: tetraploids; squares: hexaploids; colors denote taxa according to the individual legends inside each panel.

Romania, Serbia) of the distribution area, whereas tetraploids occur in intermittent areas (western Balkan Peninsula) and north of the diploids (Fig. 6). Interestingly, the isolated population from Gran Sasso in central Italy (from where the allegedly related $K$. gussonei Szabó was described) is tetraploid and AFLP data (Frajman et al., unpubl. res.) suggest that it possibly results from transadriatic migration from the Balkan Peninsula.
Hexaploid $K$. dipsacifolia is limited to the Alps and the areas north of the Alps [36], whereas tetraploids occur in western Europe, the Carpathians and the Balkans (Fig. 6; [33, 42]). In $K$. arvensis, the species with the widest distribution area [36], our geographically limited sample showed that diploids are mostly distributed in the inner part of the Alpine arch, whereas tetraploids extend from its outer margin towards the 


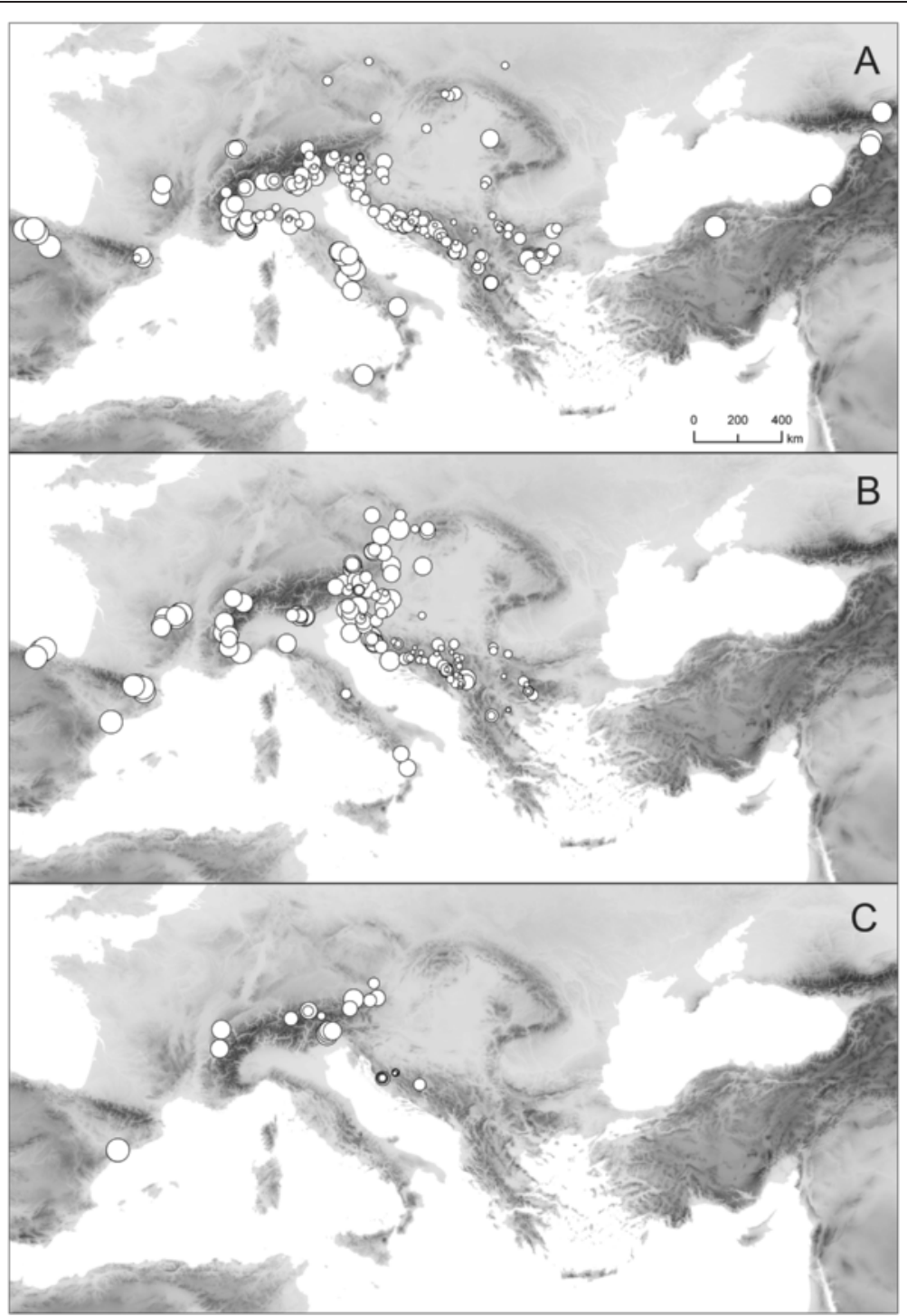

Fig. 7 Geographical distribution of monoploid relative genome size in Knautia sect. Trichera. a diploids, $\mathbf{b}$ tetraploid, and $\mathbf{c}$ hexaploids. The size of a dot is proportional to the mean relative genome size of a population

northeast and southeast, with one population (K126) also in the Kvarner Bay of the northern Adriatic. The pattern in the northeast of the distribution area reflects the results of Kolár et al. [12], with the exception that we only included diploid populations from the Czech Republic.

\section{Genome size variation in Knautia: evolutionary considerations}

Most of the results presented here are based on DAPIstained nuclei (i.e., RGS), despite its preferential binding to AT-rich regions of DNA, because only dried material was available from most populations, which is not suitable for staining with the intercalating fluorochrome propidium iodide. However, as has been shown previously
[58], the base content varies only slightly within a family and consequently, differences in fluorescence intensity of base-selective fluorochromes at low taxonomic levels (e.g., within a genus or a section) reflect variation in the total amount of nuclear DNA rather than variation in AT/GC base content [59]. Moreover, significant correlation of AGS and RGS values obtained from the same populations makes our conclusions based on RGS reliable.

The evolution of RGS shows strong correlation with the phylogeny of diploid members of Knautia (Fig. 5). Knautia integrifolia from sect. Tricheroides had the smallest monoploid RGS in the entire genus (Fig. 2), i.e. the 0.56 -fold of the mean of sect. Trichera, which corroborates the results of Temsch and Greilhuber 
[45]. Knautia integrifolia was also exceptional in terms of intraspecific RGS variation amounting to $60 \%$, based on individual measurements (Fig. 2, Table 1). The species is distributed throughout much of the Mediterranean and in spite of our restricted sampling geographycorrelated differences in RGS are manifested as the southern-most populations from Greece exhibited the smallest RGS while populations from Bulgaria, Italy and Croatia had larger RGS (Additional file 2: Table S1). Such variation in RGS is likely connected with wide distribution as well as phylogenetic heterogeneity, as the accessions of $K$. integrifolia are positioned in two or three well supported clades in ITS and plastid trees, respectively ([34], Fig. 5). Both investigated populations of $K$. cf. degenii have a similar RGS, on the lower limit of the variation exhibited by diploid members of sect. Trichera. Knautia degenii, for which no chromosome counts are available, was classified in sect. Knautia [36]. Phylogenetic analyses of ITS sequences ([34]; Fig. 5) showed its position within sect. Tricheroides and its GS is also closer to $K$. integrifolia than to $K$. orientalis. A gradual decrease in the RGS can be observed along the branch leading to sect. Tricheroides (Fig. 5). In contrast, $K$. orientalis, a member of sect. Knautia, has a RGS close to the maximum limit of the RGS variation of diploid members of sect. Trichera (Fig. 2) and, consequently, gradual increase in RGS can be observed along the branch leading to $K$. orientalis (Fig. 5). These results are in controversy with karyological data, as the base chromosome number $x=10$ occurs in both sect. Trichera and Tricheroides, whereas $K$. orientalis from sect. Knautia has $x=8$ ([36]; Fig. 5). Section Knautia is the earliest diverging lineage, whereas sect. Tricheroides is sister to sect. Trichera ([34]; Fig. 5); therefore more similar GS would be expected among diploids of the latter two lineages. Many factors, however, can influence the GS and the three lineages have likely diverged several million years ago, allowing for divergent GS evolution. Despite different chromosome numbers in sections Knautia and Trichera the GS of their diploid members is similar, whereas genome downsizing likely took place in the evolutionary history of sect. Tricheroides.

\section{Variation and geographic distribution of genome size in sect. Trichera}

Within sect. Trichera RGS variation among diploids of different species was 1.69 -fold, and among tetraploids 1.57 -fold. The lowest level of variation (1.40-fold) was among hexaploids, which are also represented by the lowest number of species (and thus of analysed samples). Several Iberian taxa have higher GS: diploid K. subscaposa had an elevated RGS (Fig. 5) intermediate between diploids and tetraploids of other taxa, whereas tetraploid $K$. legionensis, $K$. nevadensis and $K$. rupicola exhibited RGS values intermediate between the remaining tetraploids and hexaploids, and hexaploid $K$. rupicola had the highest GS of all investigated taxa (Fig. 2). Accessions of $K$. arvernensis from central France and $K$. lebrunii from the eastern Pyrenees clustering together with the abovementioned taxa in AFLP analyses (Frajman et al., unpubl. res.) had a smaller GS similar to the extraIberian members of sect. Trichera. Their similar GS, which is divergent from other taxa, provides additional evidence that the Iberian taxa are closely related, despite their different morphology (e.g., lowgrowing $K$. rupicola and $K$. subscaposa with strongly dissected leaves vs. tall-growing $K$. nevadensis with entire leaves; cf. [52]). Such GS increase was also observed in other plant groups, mostly connected with the amplification of certain classes of repetitive DNA, tandem repeats or transposable elements (Vicia, [60]; Fritillaria, [61]; Melampodium series Leucantha, [24, 49]; Prospero, [62]).

The present study revealed considerable intraspecific intra-ploidy level variation in RGS (Table 1), ranging from zero in tetraploid $K$. foreziensis endemic to a single mountain range to 1.21 -fold in diploid $K$. drymeia, which has a much wider distribution. Also in K. drymeia and $K$. integrifolia (see above) high variation in RGS can be explained by evolutionary heterogeneity [34]. Diploid $K$. drymeia has a disjunct distribution, along the southern margin of the Alps (subsp. centrifrons (Borbás) Ehrend. and subsp. tergestina (G. Beck) Ehrend.) and in the southeastern Balkan Peninsula (subsp. nympharum (Boiss. \& Heldr.) Ehrend.; Fig. 6b, [33]). Both groups are also genetically distinct (B. Frajman, unpublished AFLP data) and this could have triggered high variability in RGS. In general, the interpretation of such differences should be done with caution as several, especially widespread, Knautia species appear not to be monophyletic ([34], Frajman, unpubl. res.]). Also methodological artefacts can contribute to variability [10], but we consider the observed variation genuine from a methodological point of view. Analyses based on two different fluorochromes (PI and DAPI) gave consistent and correlated data, and simultaneous analyses of samples with different RGS yielded histograms with one bifurcate or two separate peaks (Fig. 4), which is considered the most convincing evidence for real differences in nuclear DNA content [10]. Moreover, similar differences in GS were observed in $K$. arvensis also by Kolář et al. [12]. The lack of chromosome counts for many analysed populations prevents explanation of the observed GS variation in terms of differences in the number of chromosomes (e.g. aneuploidy, dysploidy, B chromosomes). Nevertheless, intraspecific or even intrapopulation GS variation has been recently documented in several plant species [15, 63-67] indicating that genuine 
intraspecific variation in the size of the nuclear genome indeed exists.

Genome downsizing, i.e. a decrease in monoploid GS $[18,19]$ was observed in tetraploids and hexaploids of sect. Trichera. The monoploid RGS of tetraploids and hexaploids was significantly smaller than that of diploids, whereas there was no significant difference between tetraploids and hexaploids (Fig. 3). Genome downsizing following polyploidisation has been reported for other taxa and appears to be more common than genome expansion [19]. It is usually explained by elimination of repetitive or single copy DNA sequences [9, 19, 20, 68-70]. An alternative, yet untestable, hypothesis is that the parental species had smaller GS when they gave rise to a polyploid derivative. The extent of genome downsizing is group-specific but in general more pronounced in old polyploids [23, 48, 71-74].

The spatial distribution of monoploid RGS in sect. Trichera was non-random. Within di- and tetraploid cytotypes smaller monoploid RGS values were observed in the western Balkan Peninsula and the Alps. A weak, albeit statistically significant increase of monoploid RGS was observed towards the eastern, western and southern margins of the section's distribution in diploids and towards the western and northern margins in tetraploids and hexaploids (Fig. 7). A similar pattern of smaller monoploid RGS in the distribution centre, and an increase towards the margins of the range were also observed in the grass genus Sesleria, with centre of diversity in the Balkan Peninsula [75]. We are not aware, however, of other studies showing such pattern, probably also because most studies evaluating GS across multiple species of a genus did not cover their geographic distribution or did not explore the geographic distribution of monoploid GS. Future experimental studies will show whether larger GS in Knautia limits adaptive and competitive abilities of populations [76] at the genus' distribution margins and might thus represent a factor limiting further range expansion. Genome size increase is typically associated with polyploidisation or increased activity of retrotransposons [77, 78], which is often caused by stress factors, both genomic and environmental $[79,80]$. The larger genome sizes of Knautia taxa at the distribution margins might, thus, be caused by activation of certain types of retrotransposons in response to stress triggered by colonization of new habitats. Alternatively, taxa with larger genomes might have been better suited to occupy new niches.

\section{Methods}

\section{Plant material}

Plant material for GS and chromosome number estimation was collected in the field in 2010-2013 throughout the distribution range of the genus. For RGS measurements leaf material of one to ten individuals per population and one to 65 populations per species (i.e., roughly proportional to the size of the species' distribution areas) was collected and immediately desiccated in silica gel. Plants collected in the field were grown in the Botanical Garden of the University of Innsbruck and plants were used for AGS measurements and karyology.

Plant species determinations are based on Flora Europaea [33] and national floras [52, 81-83]. Herbarium vouchers were revised by F. Ehrendorfer, a taxonomic expert of the group. Five populations could not be assigned to any taxon, four of which were hexaploid from Velebit in Croatia (K. sp. 1: K102, K103, K105, K500) and one was a tetraploid from Serbia (K. sp. 2: K218).

Voucher specimens are deposited either at the Institute of Botany, University of Innsbruck, Austria (IB), the Faculty of Science, University of Zagreb, Croatia (ZA), the Faculty of Agriculture, University of Zagreb, Croatia (ZAGR), the Faculty of Biology, University of Belgrade, Serbia (BEOU) or the Natural History Museum Belgrade, Serbia (BEO; Table S1). Voucher numbers, collection details and taxonomic authorities are given in the Additional file 2: Table S1; further information on the populations can be retrieved from the publicly accessible database of the BALKBIODIV project at http://www.uibk.ac.at/botany/ balkbiodiv/?Sampling_sites.

\section{Chromosome numbers}

Chromosome numbers were determined for 14 Knautia species (Table 1). Root tip meristems were pre-treated with $0.002 \mathrm{M}$ aqueous solution of 8-hydroxyquinoline for $2 \mathrm{~h}$ at room temperature and $2 \mathrm{~h}$ at $4{ }^{\circ} \mathrm{C}$, fixed in $96 \%$ ethanol and glacial acetic acid $(3: 1)$, and stored at $-20{ }^{\circ} \mathrm{C}$ until use. Meristems were hydrolysed in $5 \mathrm{~N}$ $\mathrm{HCl}$ for $30 \mathrm{~min}$ at room temperature, washed with tap water and stained with Schiff's reagent for one hour [84]. Chromosome spreads were prepared by squashing a stained meristem in a drop of acetic acid (60\%) under the coverslip, and analysed using AxioImager M2 microscope (Carl Zeiss, Vienna, Austria). Images were acquired with a CCD camera and files processed using AxioVision ver. 4.8 (Carl Zeiss, Vienna, Austria). Chromosomes were cut out in Corel PHOTO-PAINT $\mathrm{X} 5$ and used for constructing karyotypes.

\section{Flow cytometry}

Flow cytometry (FCM) of 4,6-diamidino-2-phenylindole (DAPI; final concentration $0.036 \mathrm{M}$ ) stained nuclei was used to estimate RGS and to assess DNA ploidy levels of silica gel-dried Knautia samples [85]. The primary internal standard used to determine DNA amounts was Vicia faba cv. Inovec $(2 C=26.90 \mathrm{pg} ;[86])$. For the samples K401 and 
K402 of $K$. rupicola the internal standard was Pisum sativum cv. Kleine Rheinländerin $(2 \mathrm{C}=8.84 \mathrm{pg}$; [87] $)$ as the sample peak overlapped with that of Vicia faba. Desiccated green leaf tissue (c. $0.5 \mathrm{~cm}^{2}$ ) of two individuals from the same population were pooled together with an appropriate amount of fresh reference standard and processed as described in Suda et al. [15]. The relative fluorescence intensity of 3,000 particles was recorded using a Partec CyFlow Space flow cytometer (Partec GmbH, Münster, Germany). Partec FloMax software was used to evaluate the histograms, which were manually gated. RGS was calculated as ratio between the relative fluorescence of sample and standard. The reliability of the measurements was assessed by calculating coefficients of variation $(\mathrm{CV})$ for the $\mathrm{G}_{1}$ peaks of both the analysed sample and the reference standard. Analyses yielding a CV threshold of $>5 \%$ were discarded and the samples measured again. The number of measurements per population yielding high quality FCM histograms is given in Table 1.

AGS was determined using FCM of propidium iodide (PI) stained nuclei of 88 samples from 30 species (see Table 1), covering the entire GS variation encountered in RGS measurements. Fresh, intact leaf tissue was cochopped with leaf material of the reference standard $V$. faba cv. Inovec $(2 \mathrm{C}=26.90 \mathrm{pg}$; [86]) in Otto I buffer (0.1 M citric acid monohydrate with $0.5 \%$ Tween 20; [88]). For K. rupicola K402 the standard was Secale cereale cv. Dankovská $(2 \mathrm{C}=16.19$ pg; [89]), as the peak of this accession was overlapping with the peak of $V$. faba. Otto II buffer $\left(0.4 \mathrm{M} \mathrm{Na}_{2} \mathrm{HPO}_{4}\right)$ with $\beta$-mercaptoethanol $(2 \mu \mathrm{l} / \mathrm{ml})$, RNase $(50 \mu \mathrm{g} / \mathrm{ml})$ and PI $(50 \mu \mathrm{g} / \mathrm{ml})$ was added to the flow-through fraction and incubated for 5-15 $\mathrm{min}$. The relative fluorescence intensity of 5,000 particles was recorded. The AGS of each sample was measured three times on different days in order to eliminate system errors (the AGS of each sample is thus a mean value of three measurements). Therefore, aliquots of nuclear suspensions were preserved in $500 \mu \mathrm{l}$ glycerol $(60 \%)$ at $-20{ }^{\circ} \mathrm{C}$ as described in Kolár et al. [90]. Prior to FCM analysis, the suspension was centrifuged ( $3 \mathrm{~min}$ at $3,200 \mathrm{rpm}$ ), the supernatant was discarded and the nuclei were resuspended in $200 \mu \mathrm{l}$ of Otto I buffer. After incubation for $15 \mathrm{~min}$ at room temperature, the samples were stained with PI, incubated for 5-15 min and their GS was measured. A divergence of up to $2 \%$ between the three measurements and a CV of up to $3 \%$ was accepted.

\section{Statistical analyses}

Due to the non-normal distribution of RGS within ploidy levels (as assessed by Kolmogorov-Smirnov test) Spearman rank order correlations implemented in Statistica 12 (StatSoft Inc., Tulsa, OK, USA) were calculated to assess the relationship between RGS and
AGS across all three ploidy levels and for each ploidy level separately, as well as between ploidy level (i.e., number of complete chromosome sets) and monoploid RGS. The same analysis was used to test the relationships between monoploid RGS of a population and the geographical distance of that population from an arbitrarily defined coordinate positioned in an area with high frequency of small monoploid RGS on the western Balkan Peninsula ( $43^{\circ} 30^{\circ} \mathrm{N}, 18^{\circ} 00^{\circ} \mathrm{E}$; distances determined with ArcGIS 10, ESRI). The latter analyses were performed for the entire sect. Trichera as well as for each ploidy level separately. Finally, Kruskal-Wallis tests followed by Mann-Whitney pairwise comparisons and Bonferroni correction of $\mathrm{p}$ values conducted with PAST 3 [91] were used to test for differences in RGS and monoploid RGS among ploidy levels within sect. Trichera.

\section{Phylogenetic analyses and genome size reconstruction}

Evolution of RGS was reconstructed for diploid taxa only, for which sequences were available from the study of Rešetnik et al. [34]. For $K$. sect. Knautia and $K$. sect. Tricheroides ITS and plastid petN(ycf6-psbM) datasets from Rešetnik et al. [34] were pruned to contain all accessions for which RGS data were available; the putative hybrid K. degenii K272 was excluded. For K. sect. Trichera only two to three accessions with smallest and highest RGS per species were retained covering the entire intraspecific RGS variation. Bayesian analyses were performed for the concatenated dataset employing MrBayes 3.2.1 [92] applying the GTR $+\Gamma$ substitution model proposed by the Akaike information criterion implemented in MrAIC.pl 1.4 [93] for both datasets. The settings for the Metropolis-coupled Markov chain Monte Carlo (MC3) process included four runs with four chains each (three heated ones using the default heating scheme), run simultaneously for $10,000,000$ generations each, sampling trees every 1,000 th generation using default priors. Posterior probabilities (PPs) were determined from the combined set of trees, discarding the first 1001 trees of each run as burn-in. The evolution of RGS was mapped onto the Bayesian consensus phylogram applying the R package [94] phytools (methods contMap and phylosig; [95, 96]). We used phylosig and the implemented Chi-square test to test for the presence of phylogenetic signal, i.e. to determine whether the distribution of RGS is properly predicted by our phylogenetic hypothesis $(\lambda>0)$ or distributed randomly $(\lambda=0)$.

\section{Conclusions}

We confirmed the presence of three ploidy levels (diploids, tetraploids and hexaploids) in Knautia; diploids 
and tetraploids are widespread whereas hexaploids have a more restricted distribution. Several species are heteroploid, and in some species cytotypes exhibit geographycorrelated distribution patterns. Altogether, we show that the application of flow cytometry and chromosome counts to a comprehensive taxonomic and dense geographical sampling enables the recognition of evolutionary patterns such as the strongly deviating genome size of Iberian taxa or the centrifugal increase in genome size across ploidy levels towards the range limits of section Trichera. Further phylogeographic, phylogenetic, cytological and ecological analyses will allow elucidating causes underlying the observed patterns.

\section{Availability of supporting data}

The data sets supporting the results of this article are included within the article and its additional files.

\section{Additional files}

Additional file 1: Figure S1. Karyotypes of three diploid, two tetraploid and one hexaploid species of Knautia. Scale bar equals $5 \mu \mathrm{m}$.

Additional file 2: Table S1. Voucher information and genome size data. More information can be retrieved from http://www.uibk.ac.at/ botany/balkbiodiv/?BALKBIODIV under "Sampling sites".

\section{Competing interests}

The authors declare that they have no competing interests.

\section{Authors' contributions}

BF and PS conceived the study and did most of the sampling. HWS did the chromosomal work and FE revised the herbarium vouchers. BF and PS supervised the flow cytometric work. BF and IR did the data analyses. BF, IR and PS wrote a first version of the manuscript and received considerable input from FE and HWS. All authors read and approved the final manuscript.

\section{Acknowledgements}

We thank all collectors listed in the Additional file 2: Table S1 for samples and M. Magauer, B. Pernfuss and D. Pirkebner as well as P. Kirchweger and D. Steiner for their excellent laboratory work. We also thank P. D. Schlorhaufer and M. Bodner from the Botanical Garden of the University of Innsbruck for successfully cultivating our living collection of Knautia. Eliška Záveská helped with the GS reconstruction. Collecting permits were issued for the territory of Croatia (532-08-01-01/3-11-02 to A. Alegro), for the Parco Nazionale del Gran Sasso e Monti della Laga (UT-RAU-SCNZ 384 to S. Bogdanović) and for the Parco Nazionale della Majella (6318/3 to S. Bogdanović) in Italy, as well as for K. carinthiaca and K. norica in the federal state of Kärnten, Austria (08-NSCH140/19-2013 issued by the Amt der Kärntner Landesregierung to P. Schönswetter). The study was financed by the European Commission in the SEE-ERA.NET PLUS framework (project "Evolution, biodiversity and conservation of indigenous plant species of the Balkan Peninsula" to P.S.) and the Austria-Croatia bilateral project "Evolution of polyploid species on the Balkan peninsula" (to B. F. and A. Alegro).

\section{Author details}

${ }^{1}$ Institute of Botany, University of Innsbruck, Sternwartestraße 15, A-6020 Innsbruck, Austria. ${ }^{2}$ Faculty of Science, University of Zagreb, Marulićev trg 20/II, HR-10000 Zagreb, Croatia. ${ }^{3}$ Department of Botany and Biodiversity Research, University of Vienna, Rennweg 14, A-1030 Vienna, Austria.

Received: 10 February 2015 Accepted: 26 June 2015

Published online: 17 July 2015

\section{References}

1. Soltis DE, Albert VA, Leebens-Mack J, Bell CD, Paterson AH, Zheng C, et al. Polyploidy and angiosperm diversification. Am J Bot. 2009;96:336-48.

2. Wood TE, Takebayashi N, Barker MS, Mayrose I, Greenspoon PB, Rieseberg $\mathrm{LH}$. The frequency of polyploid speciation in vascular plants. Proc Natl Acad Sci U S A. 2009;106:13875-9.

3. Husband BC, Baldwin SJ, Suda J. The incidence of polyploidy in natural plant populations: major patterns and evolutionary processes. In: Leitch IJ, Greilhuber J, Doležel J, Wendel JF, editors. Plant Genome Diversity, vol. 2. New York: Springer; 2013. p. 255-76.

4. Madlung A. Polyploidy and its effect on evolutionary success: old questions revisited with new tools. Heredity. 2013;110:99-104.

5. Chapman MA, Abbott RJ. Introgression of fitness genes across a ploidy barrier. New Phytol. 2010;186:63-71.

6. Weiss-Schneeweiss H, Emadzade K, Jang T-S, Schneeweiss GM. Evolutionary consequences, constraints and potential of polyploidy in plants. Cytogen Genome Res. 2013;140:137-50.

7. Sonnleitner M, Flatscher R, Escobar García P, Rauchová J, Suda J, Schneeweiss GM, et al. Distribution and habitat segregation on different spatial scales among diploid, tetraploid and hexaploid cytotypes of Senecio carniolicus (Asteraceae) in the Eastern Alps. Ann Bot. 2010;106:967-77.

8. Doležel J, Greilhuber J, Suda J. Flow cytometry with plant cells. Analysis of genes, chromosomes and genomes. Wiley: Weinheim; 2007.

9. Greilhuber J. Intraspecific variation in genome size: a critical reassessment. Ann Bot. 1998:82(Suppl A):27-35.

10. Greilhuber J. Intraspecific Variation in Genome Size in Angiosperms: Identifying its Existence. Ann Bot. 2005;95:91-8.

11. Bennett MD, Bhandol $P$, Leitch IJ. Nuclear DNA amounts in angiosperms and their modern uses_-807 new estimates. Ann Bot. 2000;86:859-909.

12. Kolář F, Štech M, Trávníček P, Rauchová J, Urfus T, Vít P, et al. Towards resolving the Knautia arvensis agg. (Dipsacaceae) puzzle: primary and secondary contact zones and ploidy segregation at landscape and microgeographic scales. Ann Bot. 2009;103:963-74.

13. Marhold K, Kudoh H, Pak JH, Watanabe K, Španiel S, Lihová J. Cytotype diversity and genome size variation in eastern Asian polyploid Cardamine (Brassicaceae) species. Ann Bot. 2010;105:249-64.

14. Niketić M, Siljak-Yakovlev S, Frajman B, Lazarević M, Stevanović B, Tomović G, et al. Towards resolving the systematics of Cerastium subsection Cerastium (Caryophyllaceae): a cytogenetic approach. Bot J Linnean Soc. 2013;172:205-24.

15. Suda J, Weiss-Schneeweiss H, Tribsch A, Schneeweiss GM, Trávníček P, Schönswetter P. Complex distribution patterns of di-, tetra-, and hexaploid cytotypes in the european high mountain plant Senecio carniolicus (Asteraceae). Am J Bot. 2007:94:1391-401.

16. Trávníček P, Kubátová B, Čurn V, Rauchová J, Krajníková E, Jersáková J, et al. Remarkable coexistence of multiple cytotypes of the Gymnadenia conopsea aggregate (the fragrant orchid): evidence from flow cytometry. Ann Bot. 2011;107:77-87.

17. Soltis DE, Soltis PS. Polyploidy: recurrent formation and genome evolution. Trends Ecol Evol. 1999;14:348-52.

18. Verma SC, Rees H. Nuclear DNA and evolution of allotetraploid Brassicaceae. Heredity. 1974;33:61-8.

19. Leitch IJ, Bennett MD. Genome downsizing in polyploidy plants. Biol J Linnean Soc. 2004;82:651-63.

20. Renny-Byfield S, Kovarik A, Kelly L, Macas J, Novak P, Chase MW, et al. Diploidization and genome size change in allopolyploids is associated with differential dynamics of low- and high-copy sequences. Plant J. 2013;74:829-39.

21. Pellicer J, Kelly LJ, Leitch IJ, Zomlefer WB, Fay MF. A universe of dwarfs and giants: genome size and chromosome evolution in the monocot family Melanthiaceae. New Phytol. 2014;201:1484-97.

22. Jakob SS, Meister A, Blattner FR. Considerable genome size variation of Hordeum species (Poaceae) is linked to phylogeny, life form, ecology, and speciation rates. Mol Biol Evol. 2004;21:860-9.

23. Leitch IJ, Hanson L, Lim KY, Kovarik A, Chase MW, Clarkson JJ, et al. The ups and downs of genome size evolution in polyploid species of Nicotiana (Solanaceae). Ann Bot. 2008;101:805-14.

24. Weiss-Schneeweiss H, Blöch C, Turner B, Villaseñor JL, Stuessy TF, Schneeweiss GM. The promiscuous and the chaste: frequent allopolyploid speciation and its genomic consequences in American daisies (Melampodium sect. Melampodium; Asteraceae). Evolution. 2012;66:211-28. 
25. Balao F, Casimiro-Soriguer R, Talavera M, Herrera J, Talavera S. Distribution and diversity of cytotypes in Dianthus broteri as evidenced by genome size variations. Ann Bot. 2009;104:965-73.

26. Hülber K, Sonnleitner M, Flatscher R, Berger A, Dobrovsky R, Niessner S, et al. Ecological segregation drives fine-scale cytotype distribution of Senecio carniolicus in the Eastern Alps. Preslia. 2009:81:309-19.

27. Kim S, Rayburn AL, Parrish A, Lee DK. Cytogeographic distribution and genome size variation in prairie cordgrass (Spartina pectinata Bosc ex Link). Plant Mol Biol Rep. 2012;30:1073-9.

28. Suda J, Kron P, Husband BC, Trávníček P. Flow cytometry and ploidy: applications in plant systematics, ecology and evolutionary biology. In: Doležel J, Greilhuber J, Suda J, editors. Flow cytometry with plant cells Analysis of genes, chromosomes and genomes. Weinheim: Wiley- $\mathrm{VCH}_{\text {; }}$ 2007. p. 103-30.

29. Bigazzi M, Selvi F. Karyotype morphology and cytogeography in Brunnera and Cynoglottis (Boraginaceae). Bot J Linnean Soc. 2001;136:365-78.

30. Cook RE, Semple JC. Cytogeography of Solidago subsect. Glomeruliflorae (Asteraceae: Astereae). Botany. 2008;86:1488-96.

31. Olšavská K, Perný M, Löser CJ, Stimper R, Hodálová I. Cytogeography of European perennial species of Cyanus (Asteraceae). Bot J Linnean Soc. 2013:173:230-57.

32. Trávníček P, Jersáková J, Kubátová B, Krejcíková J, Bateman RM, Lucanová M, et al. Minority cytotypes in European populations of the Gymnadenia conopsea complex (Orchidaceae) greatly increase intraspecific and intrapopulation diversity. Ann Bot. 2012;110:977-86.

33. Ehrendorfer F. Knautia L. In: Tutin T, Heywood VH, Burges NA, Valentine DH, editors. Flora Europaea, vol. 4. Cambridge: Cambridge University Press; 1976. p. 60-7.

34. Rešetnik I, Frajman B, Bogdanović S, Ehrendorfer F, Schönswetter $P$. Disentangling relationships among the diploid members of the intricate genus Knautia (Caprifoliaceae, Dipsacoideae). Mol Phylogenet Evol. 2014;74:97-110.

35. Ehrendorfer F. Beiträge zur Phylogenie der Gattung Knautia (Dipsacaceae), I. Cytologische Grundlagen und allgemeine Hinweise. Oesterr Bot Z. 1962;109:276-343.

36. Ehrendorfer F. Neue Beiträge zur Karyosystematik und Evolution der Gattung Knautia (Dipsacaceae) in den Balkanländern. Bot Jahrb Syst. 1981;102:225-38

37. Kachidze N. Karyologische Studien über die Familie der Dipsacaceae. Planta. 1929;7:482-502.

38. Sintes S, Cauderon Y. Premier inventaire caryologique des Knautia d'Auvergne. C R Acad Sci. 1965;260:4249-51.

39. Breton-Sintes S. Etude biosystématique du genre Knautia (L.) Coult. en Auvergne. PhD Thesis, University of Clermont-Ferrand, France; 1971.

40. Ehrendorfer F. Knautia. In: Moore DM, editor. Flora Europaea Check-list and Chromosome Index. Cambridge: Cambridge University Press; 1982. p. 221-2.

41. Štěpánek J. Eine neue Art der Gattung Knautia (Dipsacaceae) aus den West Karpaten. Preslia. 1983:55:1-8

42. Verlaque R: Étude biosystématique et phylogénétique des Dipsacaceae. II-IV. Revue de Cytologie et de Biologie Végétales - le Botaniste 1985-1986, 8:117-168, 171-243; 9:5-72, 97-176.

43. Strid A. Chromosome Number Reports 93. Taxon. 1986:35:901-2.

44. Kolář F, Fér T, Štech M, Trávníček P, Dušková E, Schönswetter $P$, et al Bringing together evolution on serpentine and polyploidy: spatiotemporal history of the ecologically differentiated diploid-tetraploid complex of Knautia arvensis (Dipsacaceae). PLoS One. 2012;7:e39988.

45. Temsch EM, Greilhuber J. Genome size in Dipsacaceae and Morina longifolia (Morinaceae). Plant Syst Evol. 2010;289:45-56.

46. Siljak-Yakovlev S, Pustahija F, Šolić EM, Bogunić F, Muratović E, Bašić N, et al. Towards a genome size and chromosome number database of Balkan flora: C-values in 343 taxa with novel values for 242. Adv Sci Lett. 2010;3:190-213.

47. Suda J, Krahulcová A, Trávníček P, Krahulec F. Ploidy level versus DNA ploidy level: an appeal for consistent terminology. Taxon. 2006;55:447-50.

48. Weiss-Schneeweiss H, Schneeweiss GM, Stuessy TF, Mabuchi T, Park JM, Jang CG, et al. Chromosomal stasis in diploids contrasts with genome restructuring in auto- and allopolyploid taxa of Hepatica (Ranunculaceae). New Phytol. 2007;174:669-82.

49. Rebernig CA, Weiss-Schneeweiss H, Blöch C, Turner B, Stuessy TF, Obermayer R, et al. The evolutionary history of the white-rayed species of Melampodium (Asteraceae) involved multiple cycles of hybridization and polyploidization. Am J Bot. 2012;99:1043-57.
50. Krejčíková J, Sudová R, Lucanová M, Trávníček P, Urfus T, Vít P, et al. High ploidy diversity and distinct patterns of cytotype distribution in a widespread species of Oxalis in the Greater Cape Floristic Region. Ann Bot 2013;111:641-9.

51. Weiss-Schneeweiss H, Greilhuber J, Schneeweiss GM. Genome size evolution in holoparasitic Orobanche (Orobanchaceae) and related genera. Am J Bot. 2006;93:148-56.

52. Devesa JA. Knautia L. In: Devesa JA, Gonzalo R, Herrero A, editors. Flora Iberica. Plantas vasculares de la Península Ibérica e Islas Baleares. Vol. XV, Rubiaceae-Dipsacaceae. Madrid: Real Jardín Botánico, CSIC; 2007. p. 286-305.

53. Frajman B, Oxelman B. Reticulate phylogenetics and phytogeographical structure of Heliosperma (Sileneae, Caryophyllaceae) inferred from chloroplast and nuclear DNA sequences. Mol Phylogenet Evol. 2007:43:140-55.

54. Peruzzi L, Bartolucci F, Astuti G, Bernardo L, Conti F. Knautia dinarica (Caprifoliaceae): taxonomy, typification and update of the Italian distribution. Phytotaxa. 2013;116:34-40.

55. Turrill WB. The plant-life of the Balkan peninsula. A phytogeographical study. Oxford: Clarendon; 1929.

56. Gridelli E. II problema delle specie a diffusione attuale transadriatica con particolare riguardo ai Coleotteri. B Zool. 1950;17(S2):421-41.

57. Correggiari A, Roveri M, Trincardi F. Late Pleistocene and Holocene evolution of the north Adriatic sea. II Quaternario. 1996;9:697-704.

58. Barow M, Meister A. Lack of correlation between AT frequency and genome size in higher plants and the effect of nonrandomness of base sequences on dye binding. Cytometry. 2002;47:1-7

59. Kolář F, Lučanová M, Vít P, Urfus T, Chrtek J, Fér T, et al. Diversity and endemism in deglaciated areas: Ploidy, relative genome size and niche differentiation in the Galium pusillum complex (Rubiaceae) in Northern and Central Europe. Ann Bot. 2013;111:1095-108

60. Macas J, Požárková D, Navrátilová A, Nouzová M, Neumann P. Two new families of tandem repeats isolated from genus Vicia using genomic self-priming PCR. Mol Genet Genomics. 2000;263:741-51.

61. Ambrozová K, Mandáková T, Bures P, Neumann P, Leitch IJ, Koblízková A, et al. Diverse retrotransposon families and an AT-rich satellite DNA revealed in giant genomes of Fritillaria lilies. Ann Bot. 2011;107:255-68.

62. Jang T-S, Emadzade K, Parker J, Temsch EM, Leitch AR, Speta F, et al. Chromosomal diversification and karyotype evolution of diploids in the cytologically diverse genus Prospero (Hyacinthaceae). BMC Evol Biol. 2013;13:136

63. Šmarda $P$, Bureš $P$. Intraspecific DNA content variability in Festuca pallens on different geographical scales and ploidy levels. Ann Bot. 2006;98:665-78

64. Šmarda P, Bureš P, Horová L, Rotreklová O. Intrapopulation genome size dynamics in Festuca pallens. Ann Bot. 2008;102:599-607.

65. Slovák M, Vít P, Urfus T, Suda J. Complex pattern of genome size variation in a polymorphic member of the Asteraceae. J Biogeogr. 2009;36:372-84.

66. Cires E, Cuesta C, Revilla MA, Prieto JAD. Intraspecific genome size variation and morphological differentiation of Ranunculus parnassifolius (Ranunculaceae), an Alpine-Pyrenean-Cantabrian polyploid group. Biol J Linnean Soc. 2010;101:251-71.

67. Duchoslav M, Šafářová L, Jandová M. Role of adaptive and non-adaptive mechanisms forming complex patterns of genome size variation in six cytotypes of polyploid Allium oleraceum (Amaryllidaceae) on a continental scale. Ann Bot. 2013;111:419-31.

68. Ozkan H, Levy AA, Feldman M. Allopolyploidy-induced rapid genome evolution in the wheat (Aegilops-Triticum) group. Plant Cell. 2001;13:1735-47.

69. Feldman M, Levy AA. Allopolyploidy - a shaping force in the evolution of wheat genomes. Cytogen Genome Res. 2005;109:250-8.

70. Lysak MA, Koch MA, Beaulieu JM, Meister A, Leitch IJ. The dynamic ups and downs in genome size evolution in Brassicaceae. Mol Biol Evol. 2009;21:85-98

71. Clarkson JJ, Lim KY, Kovarik A, Chase MW, Knapp S, Leitch AR. Long-term genome diploidization in allopolyploid Nicotiana section Repandae (Solanaceae). New Phytol. 2005;168:241-52.

72. Mandakova T, Joly S, Krzywinski M, Mummenhoff K, Lysak MA. Fast diploidization in close mesopolyploid relatives of Arabidopsis. Plant Cell. 2010;22:2277-90

73. Doyle JJ. Polyploidy in legumes. In: Soltis PS, Soltis DE, editors. Polyploidy and Genome Evolution. Heidelberg: Springer; 2012. p. 147-80. 
74. Soltis DE, Buggs RJA, Barbazuk WB, Chamala S, Chester M, Gallagher JP, et al. The early stages of polyploidy: rapid and repeated evolution in Tragopogon. In: Soltis PS, Soltis DE, editors. Polyploidy and Genome Evolution. Heidelberg: Springer; 2012. p. 271-92.

75. Lazarević M, Kuzmanović N, Lakušić D, Alegro A, Schönswetter P, Frajman B: Patterns of cytotype distribution and genome size variation in the genus Sesleria Scop. (Poaceae). Bot J Linnean Soc. In press.

76. Knight CA, Molinari NA, Petrov DA. The large genome constraint hypothesis: evolution, ecology and phenotype. Ann Bot. 2005;95:177-90.

77. Bennetzen JL. Mechanisms and rates of genome expansion and contraction in flowering plants. Genetica. 2002;115:29-36.

78. Weiss-Schneeweiss H, Schneeweiss GM. Karyotype diversity and evolutionary trends in angiosperms. In: Leitch IJ, Greilhuber J, Dolezel J, Wendel JF, editors. Plant Genome Diversity Volume 2, Physical Structure and Evolution of Plant Genomes. Berlin: Springer; 2013. p. 209-30.

79. Kumar A, Bennetzen JL. Plant retrotransposons. Annu Rev Genet. 1999:33:479-532

80. Bui QT, Grandbastien M-A. LTR retrotransposons as controlling elements of genome response to stress. In: Grandbastien M-A, Casacuberta J, editors. Plant Transposable Elements: Impact on Genome Structure and Function. Heidelberg: Springer; 2012. p. 273-96.

81. Matthews VA. Knautia L. In: Davis PH, editor. Flora of Turkey and East Aegean Islands, 4. Edinburgh: University Press; 1972. p. 598-601.

82. Diklić N. Dipsacaceae B. Juss. In: Josifović M, editor. Flora SR Srbije, vol. 5. Beograd: Srpska Akademija Nauka i Umetnosti; 1973. p. 536-84.

83. Ehrendorfer F. Knautia. In: Pignatti S, editor. Flora d'Italia, vol. 2. Bologna: Edagricole; 1982. p. 664-70.

84. Weiss-Schneeweiss H, Stuessy TF, Villaseñor JL. Chromosome numbers, karyotypes, and evolution in Melampodium (Asteraceae). Int J Plant Sci. 2009;170:1168-82

85. Suda J, Trávníček P. Estimation of relative nuclear DNA content in dehydrated plant tissues by flow cytometry. In: Robinson JP, Darzynkiewicz Z, Dobrucki J, Hyun WC, Nolan JP, Orfao A, Rabinovich PS, editors. Current protocols in cytometry. New York: Wiley; 2006. p. 7.30.1-7.30.14.

86. Doležel J, Sgorbati S, Lucretti S. Comparison of three DNA fluorochromes for flow cytometric estimation of nuclear DNA content in plants. Physiol Plant. 1992;85:625-31.

87. Greilhuber J, Ebert I. Genome size variation in Pisum sativum. Genome. 1994:37:646-55

88. Otto F. DAPI staining of fixed cells for high-resolution flow cytometry of nuclear DNA. Methods Cell Biol. 1990;33:105-10.

89. Doležel J, Greilhuber J, Lucretti S, Meister A, Lysák MA, Nardi L, et al. Plant genome size estimation by flow cytometry: inter-laboratory comparison. Ann Bot. 1998:82(Suppl A):17-26.

90. Kolář F, Lučanová M, Těšitel J, Loureiro J, Suda J. Glycerol-treated nuclear suspensions - an efficient preservation method for flow cytometric analysis of plant samples. Chromosome Res. 2012;20:303-15.

91. Hammer $\breve{R}$, Harper DAT, Ryan PD. PAST: Paleontological statistics software package for education and data analysis. Paleontol Eletronica. 2001;4:9-9.

92. Ronquist F, Teslenko M, van der Mark P, Ayres DL, Darling A, Höhna S, et al. MrBayes 3.2: Efficient Bayesian phylogenetic inference and model choice across a large model space. Syst Biol. 2012;61:539-42.

93. Nylander JAA. MrAIC pl. Program distributed by the author. Uppsala: Evolutionary Biology Centre, Uppsala Universit; 2004.

94. R Development Core Team. R: A Language and Environment for Statistical Computing. Vienna: R Foundation for Statistical Computing; 2011.

95. Revell $L$. phytools: an R package for phylogenetic comparative biology (and other things). Methods Ecol Evol. 2012;3:217-23.

96. Revell $L$. Two new graphical methods for mapping trait evolution on phylogenies. Methods Ecol Evol. 2013;4:754-9.

\section{Submit your next manuscript to BioMed Central and take full advantage of:}

- Convenient online submission

- Thorough peer review

- No space constraints or color figure charges

- Immediate publication on acceptance

- Inclusion in PubMed, CAS, Scopus and Google Scholar

- Research which is freely available for redistribution

Submit your manuscript at www.biomedcentral.com/submit 